Florida International University FIU Digital Commons

7-6-1989

\title{
The status and ecology of the American alligator (Alligator mississippiensis) in Par Pond, Savannah River site
}

Laura A. Brandt

Florida International University

DOI: $10.25148 /$ etd.FI14051824

Follow this and additional works at: https://digitalcommons.fiu.edu/etd

Part of the Biology Commons

\section{Recommended Citation}

Brandt, Laura A., "The status and ecology of the American alligator (Alligator mississippiensis) in Par Pond, Savannah River site" (1989). FIU Electronic Theses and Dissertations. 1788.

https://digitalcommons.fiu.edu/etd/1788

This work is brought to you for free and open access by the University Graduate School at FIU Digital Commons. It has been accepted for inclusion in FIU Electronic Theses and Dissertations by an authorized administrator of FIU Digital Commons. For more information, please contact dcc@fiu.edu. 
THE STATUS AND ECOLOGY OF THE AMERICAN ALLIGATOR (ALLIGATOR MISSISSIPPIENSIS) IN PAR POND, SAVANNAH RIVER SITE

\section{by}

Laura A. Brandt

A thesis submitted in partial fulfillment of the requirements for the degree of

MASTER OF SCIENCE

in

BIOLOGICAL SCIENCES

at

FLORIDA INTERNATIONAL UNIVERSITY

Committee in charge:

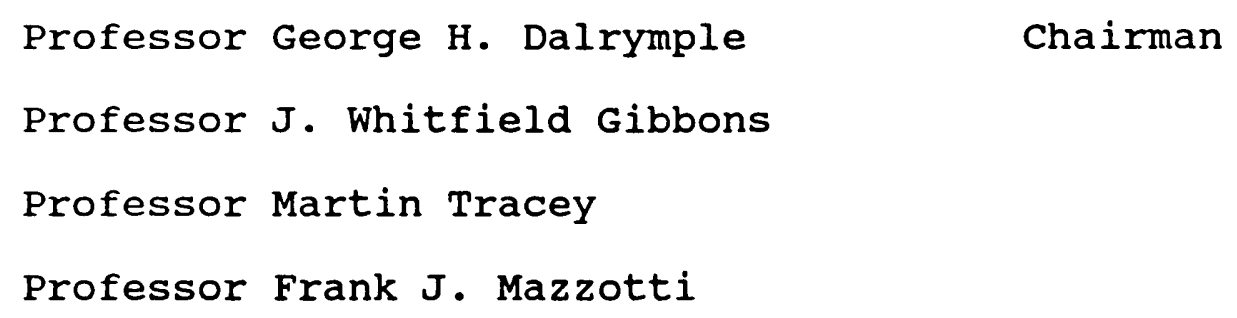


To Professors George H. Dalrymple, J. Whitfield Gibbons, Martin Tracey, Frank J. Mazzotti

This thesis, having been approved in respect to form and mechanical execution, is referred to you for judgment upon its substantial merit.

Dean James A. Mau

The thesis of Laura A. Brandt is approved.

Professor

Professor

Professor

Major Professor

Date of Examination: 6 July 1989 


\begin{abstract}
THE STATUS AND ECOLOGY OF THE AMERICAN ALLIGATOR (ALLIGATOR MISSISSIPPIENSIS) IN PAR POND, SAVANNAH RIVER SITE

by

Laura A. Brandt
\end{abstract}

Par Pond is a man-made 1120 ha cooling reservoir located on the Savannah River Site near Aiken, South Carolina. From 1972-1978 a detailed study on the status of the alligator in Par Pond was conducted by Tom Murphy (unpub. MS thesis Univ. of GA, 1977). Murphy estimated that approximately 110 alligators inhabited Par Pond with an adult ( $>1.8 \mathrm{~m})$ to juvenile $(<1.8 \mathrm{~m})$ ratio of $(1.8: 1)$, an overall sex ratio of $3.2: 1$, and an average of only 2.3 nests/yr. The purpose of this study (1986-1989) was to determine the current population size and structure, determine how the population has changed in the last 15 years and to examine growth and survival of juvenile alligators.

Data were collected by monthly night-time eyeshine counts aerial surveys, capturing animals, and locating and following the fate of nests. There was a strong positive correlation between water temperature and the number of alligators observed during eyeshine counts. Both eyeshine counts and aerial surveys were highest in spring and varied seasonally. 
A total of 184 different non-hatuhling and 157 hatchling alligators were captured between May 1986 and November 1989. Population estimates and size distributions based on capture data indicate that over the last 15 years the population has increased from approximately 110 to 200 alligators, and the size distribution has shifted from one dominated by large adults to one that has a higher proportion of juveniles. The current sex ratio $(2.6: 1)$ is not significantly different from that reported by Murphy $(1977,3.2: 1)$. However, the average number of nests/yr has increased from 2.3 to 4.0 .

Data on juvenile growth and survival show that the growth rate of hatchlings $\left(32.9 \mathrm{~cm} / \mathrm{yr}^{\mathrm{r}}\right.$ total $\left.1 \mathrm{e} . \mathrm{gth}\right)$ is greater than that of animals age 1-3 $(21.6 \mathrm{~cm} / \mathrm{yr}$ total length) and survival of all àges is variable between years and between clutches.

Results from this study indicate that from 1972-1988 the population has increased ac an average exponential rate of $6 \%$ per year. If conditions in Pax Pond do not change, the population size should continue to increase.

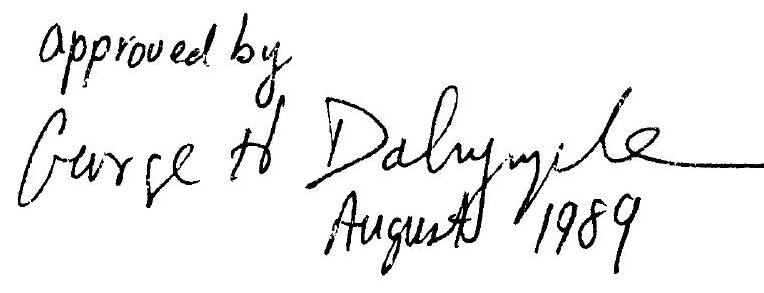


THE STATUS AND ECOLOGY OF THE AMERICAN ALLIGATOR

(ALLIGATOR MISSISSIPPIENSIS) IN PAR POND, SAVANNAH RIVER SITE

by

Laura A. Brandt

A tiesis submitted in partial fulfillment of the requirements for the degree of

MASTER OF SCIENCE

in

BIOLOGICAL SCIENCES

at

FLORIDA INTERNATIONAL UNIVERSTTY

1989 
Ccopyright by

\section{LAURA A. BRANDT}

1989 


\section{PREFACE}

The American alligator (Alligator mississippiensis) is the best studied of the 21 extant species of crocodilians (Brisbin et al 1986). Alligator populations have fluctuated from relatively high numbers in the 1800s, to dangerously low numbers in the 1960 s, to over 800,000 range-wide at the present time (Groombridge 1987). The increase in the number of alligators is due to habitat protection and controlled hunting as required by the Endangered species Act, an increase in knowledge of alligator biology (and hence, better decisions concerning alligator management), and the ability of alligators to take advantage of virtually any aquatic habitat.

Alligators occur throughout the southeastern United States from North Carolina to south Florida and west into Texas. Populations in Louisiana (McIlhenny 1935; Chabreck 1966; Joanen 1969; Joanen and McNease 1970, 1972, 1975; McNease and Joanen 1974, 1978) and Florida (Hines et al 1968; Fogarty 1974; Deitz and Hines 1980; Goodwin and Marion 1978, 1979) have been the focus for most of the research conducted on alligators including habitat requirements, population structure, growth rates, and size at maturity. Many of these parameters have been used to construct models for management and harvesting programs. Much of the limited body of literature on alligators from North and South Carolina is unpublished reports or theses (Bara 1971, 1972, 1973; Murphy 1977; Fuller 1981; Murphy and Fuller 1982). 
Research conducted in South Carolina suggests that alligators in the northern portion of the range grow more slowly than those in Louisiana and therefore take 13-17 years to reach maturity (Murphy and Fuller 1982), compared to 8-10 years in Louisiana (Joanen and McNease 1975). These and other parameters, which may vary with latitude, could have a substantial effect on the population biology of alligators in more northern areas, and therefore on patterns of colonization and recovery from a decrease in numbers. If appropriate decisions are to be made concerning alligator management in these areas, basic biological information on the population biology of alligators in the northern portion of the range is needed.

Par Pond, the study area for this research, is an 1120 ha reservoir located on the Savannah River Site (SRS) near Aiken, South Carolina. There are several advantages to working on Par Pond and at the SRS: 1) The SRS is in the northwestern portion of the alligator's range and work here will provide information on alligator biology from a region from which data are limited. 2) Par Pond is closed to the public and the population is not subject to harvesting (either controlled or uncontrolled) so that natural patterns of change can be followed, and 3) there is already a database on population characteristics for this population from a study conducted by Tom Murphy from 1972-1978 (Murphy $1977,1981)$.

The purpose of my study was to evaluate the current 
status of the alligator population in Par Pond by obtaining basic biological information on growth rates, sex ratios and size structure of the population. This information will then be compared to similar data from the Par Pond population 15 years ago and to populations in habitats and locations.

This thesis has been divided into three chapters to address the following: 1) What is the current population size and structure (i.e., number of alligators, sex ratio, and size distribution) and how has this changed from the 1970s? 2) What is the relationship between night-time eyeshine counts, aerial surveys, and population estimates based on mark-recapture techniques? 3) What are the characteristics of growth and survivorship of juvenile alligators in Par Pond?

This study was supported by the Savannah River Ecology Laboratory, Division of Stress and Wildlife through a Department of Energy contract to the University of Georgia (DE-AC09-76SROO-819), the Graduate Student Education Program, and Oak Ridge Associated Universities Graduate Student Travel contract (T-417).

I would like to thank all of the people at SREL who "volunteered" their time to help with all aspects of this study. Without them I would not have been able to complete this project. Special thanks goes to the Herp Crew: Sarah Collie, Ruth Estes, Marie Fulmer, Bud Fischer, Whit Gibbons, Judy Greene, Mary Jackson, David Kling, Jim Knight, Brian 
Maddox, Tony Mills, Tim Owens, Joe Pechmann, David Scott, and Rich Seigel for their assistance and friendship throughout this study. The following people provided assistance (sometimes above and beyond the call of duty) capturing alligators: David Scott, Mary Jackson, Tony Mills, Howard Zippler, David Kling, Tim Owens, Bobby Kennamer, Bill Harvey, Frank Mazzotti, Scott Busa, Bob Nodell, and Luke Hasty. My committee, Drs George Dalrymple, Whit Gibbons, Marty Tracey, and Frank Mazzotti offered support and encouragement throughout this study. Phil Dixon and Joe Pechmann provided statistical advice. Bill Mccort offered administrative and moral support. Jerry Garvin, Fred stone and the rest of the CMC provided invaluable assistance in fabrication and maintenance. I thank Tom Murphy for giving me access to his data and sharing his thoughts on Par Pond alligators with me. I would also like to thank my parents, Gerald and Susan Brandt for their encouragement and understanding throughout this study. 
TABLE OF CONTENTS

LIST OF TABLES . . . . . . . . . . . . . . . . . viii

LIST OF FIGURES . . . . . . . . . . . . . . . . ix

CHAPTER ONE

ECOLOGY OF THE AMERICAN ALLIGATOR IN PAR POND,

SOUTH CAROLINA . . . . . . . . . . . . . . . . . . . 1

INTRODUCTION . . . . . . . . . . . . . . . 1

METHODS . . . . . . . . . . . . . . . . . 4

RESULTS . • . • . . . . . . . . . . . . . 8

DISCUSSION . . . . . . . . . . . . . . . 18

CHAPTER TWO

AERIAL SURVEYS, NIGHT COUNTS, AND MARK-RECAPTURE;

A COMPARISON OF THREE TECHNIQUES FOR ESTIMATING ALLIGATOR POPULATION SIZE.

INTRODUCTION . . . . . . . . . . . . . 23

METHODS ........................ 26

RESULTS . . . . . . . . . . . . . . . . 31

DISCUSSION . . . . . . . . . . . . . . 4 47

CHAPTER THREE

GROWTH AND SURVIVAL OF JUVENILE ALLIGATORS IN

PAR POND. . . . . . . . . . . . . . . . . 51

INTRODUCTION ................... 51

METHODS . . . . . . . . . . . . . . 53

RESULTS . . . . . . . . . . . . . . . . 57

DISCUSSION . . . . . . . . . . . . . . 68

CHAPTER FOUR

SUMMARY AND CONCLUSIONS . . . . . . . . . . . 76

APPENDIX A . . . . . . . . . . . . . . . . 79

APPENDIX B . . . . . . . . . . . . . . . 80 
APPENDIX C . . . . . . . . . . . . . . . 81

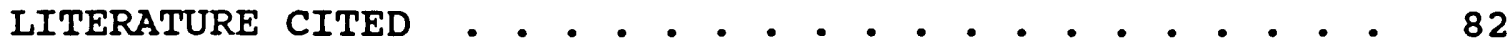

VITA . . . . . . . . . . . . . . . 89 
Table 1. Jolly-Seber estimates base, $n$ captures for alligators $\leq 1.25 \mathrm{~m}$ and $\mathrm{Lin}=0$ - $n$-Peterson population estimates for aliigators $\geq 1.5 \mathrm{~m}$ based on aerial survi y data. . . .

Table 2. Estimated population size and sex ratios for alligators inhabiting $\mathrm{Par}$ ond in 1972-1974 and 1986-1988. 1974 data ire from Murphy 1977. 1988 total population size includes 6 animals 1.25-1.5 m that were cart red but not represented in either est mate. . . . . 15

Table 3: Clutch and egg sizes fror alligator nests in Par Pond. * indicat ss minimum number hatched. ILL=Ilehr's Inlet, GG=Gentry's Gulf, SS=Susan's Swamp, MM=Mike's Marsh, LL=Loyal's Lair (see Appendix B for nest ard pod locations). . . 58

Table 4a: Hatchling morphometric data. Number in () corresponds to nests from Table 3 . Nests without numbers were found after hatching. Hatchling lengths and weights are within one week of hatching unless otherwise noted. .

Table 4b: Skull length and width data (cm) for hatchling alligators. Number in () corresponds to nests from Table 3 . Nests without numbers were found after hatching.

Table 5. Morphometric data of known-age alligators from Par Pond. Age is in months. Values are means \pm SD. . . . . . . . . . . . .

Table 6: Cumulative and (interval) MKA survival rates for juvenile alligators from 5 clutches (4 from 1985, 1 from 1987) in Par Pond, orange Lake, Florida (Woodward et al, 1987), and from a computer model (Nichols 1976). . 
Figure 1. Size class distribution for 183 non-hatchling alligators captured in Par Pond 1986-1988 (this study) and 1974-1976 (Murphy, 1977). . . . . . . . . .

Figure 2. Size and sex structure of 183 non-hatchling alligators captured in Par Pond 1986-1988.

Figure 3. Average annual exponential rate of increase (r) for the Par Pond alligator population from 1971-1988 (1971-1978 data are from Bara, 1971, 1972, 1973, 1974; Murphy 1981).

Figure 4. Temperature stations (A-E) used during night time eyeshine counts of alligators in Par Pond. . . . . . . . . . . . . 28

Figure 5. Mean number and range of alligators sighted during monthly night-time eyeshine counts on Par Pond from July 1987 - sept 1988 $(\triangle \cdots \triangle, n=46)$ and July 1972 - Sept 1973 (O -,$n=31)$. 1972-1973 data are from Murphy 1977.

Figure 6. Relationship between number of alligators counted and water temperature during night surveys on Par Pond from July 1987 July $1988(n=32)$. . . . . . . . . . .

Figure 7. Relationship between estimated size and real size of alligators observed during aerial surveys $(n=15)$ and night counts $(n=50)$. . . . . . . . . . .

Figure 8. Number of alligators sighted during day time aerial surveys $(O)$ and night time eyeshine counts $(\triangle)$ on Par Pond from October 1987 October 1988. . . . . . . . . . . . .

Figure 9. Percent composition of alligators $\geq 1.5 \mathrm{~m}$ observed during aerial surveys $(\square)$ from October 1987-October 1988 (269 sightings), and from captures $(\square)$ October 1986 - october $1988(n=45)$. . . . . . . . . . . . . . 43

Figure 10. Relationship between the number of alligators $>1 \mathrm{~m}$ observed in night counts and aerial surveys conducted from October 1987-september

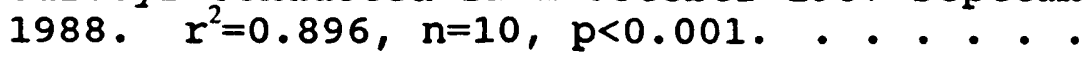


Figure 11. Snout vent length (SVL) of known-age alligators captured in Par Pond, South Carolina from May 1986-October $1988(\mathrm{n}=118)$. . . . . . . 63

Figure 12. Condition factor of non-hatchling alligators captured in Par Pond, South Carolina from May 1986-October 1988 (312 records). . . . 65 
CHAPTER ONE

ECOLOGY OF THE AMERICAN ALLIGATOR IN PAR POND, SOUTH CAROLINA

\section{INTRODUCTION}

The American alligator (Alligator mississippiensis) is one of the few species of crocodilians which is not currently in danger of extinction. This was not always the case. Alligator populations have fluctuated from relatively high numbers in the 1800 s to very low numbers in the 1960s to over 800,000 at the present time (Groombridge 1987). The increase in numbers has been the result of protective legislation, including the Endangered Species Act, and research on basic alligator biology that has allowed for the establishment of appropriate management plans. Although the alligator is the best studied crocodilian (Brisbin et al 1986) and has a wide distribution within the United States (North Carolina to Florida and west to Texas), most studies have concentrated in Louisiana (McIlhenny 1935; Chabreck 1966; Joanen 1969; Joanen and McNease 1970, 1972, 1975; McNease and Joanen 1974, 1978) and Florida (Hines et al 1968; Fogarty 1974; Deitz and Hines 1980; Goodwin and Marion 1978, 1979). Few studies have been conducted in North and South Carolina (Bara 1971, 1972, 1973; Murphy 1977; Fuller 1981; Murphy and Fuller 1982).

The rate at which populations change in size and structure is dependent on the rate of recruitment into reproductive size classes, and this is dependent on growth rates and age at maturity. If juvenile alligators in south 
Carolina indeed grow more slowly than those in Louisiana as earlier studies indicate $(15.0 \mathrm{~cm} / \mathrm{Yr}$ total length in $\mathrm{SC}$ (Murphy and Fuller 1982) vs $35.0 \mathrm{~cm} / \mathrm{yr}$ total length in LA (McIlhenny 1935) and alligators in South Carolina take 13-17 years to mature (Murphy and Fuller 1982) vs 8-10 years in Louisiana (Joanen and McNease 1975) then models of population growth which are applicable to Louisiana alligator populations (Nichols 1976; Nichols et al 1976) are inappropriate for South Carolina alligator populations. Much of the information needed for construction and verification of this type of model is not available for alligators in South Carolina.

One problem in studying alligator population dynamics is that alligators are slow-growing and long-lived, so that changes in population size and structure occur over decades. For this reason few long-term studies have been conducted on non-harvested alligator populations. At Par Pond, Savannah River Site, Aiken, South Carolina I had opportunity to study an alligator population protected from hunting and at the northern portion of the alligator's range. Comparison of the population characteristics with those of the 1970 s was possible because of earlier studies. Studies conducted in Par Pond from 1972-1978 (Murphy 1977, 1981) indicated that the population of alligators in Par Pond was made up of approximately 110 alligators (2.1 alligators $/ \mathrm{km}$ ) with a 3.2:1 sex ratio, a high proportion of adults (64\%), relatively few juveniles $(<1.8 \mathrm{~m})$ and low reproduction $(2.3$ 
3

nests/Yr, Murphy 1977). Murphy (1981) estimated that Par Pond could support a population of approximately 500 individuals $(9.4 / \mathrm{km})$, but that with its size and sex distribution biased toward adult males, and the consequent low reproduction the population size would remain the same or decrease. The purpose of this study was to determine the status of the Par Pond population and to compare the current population size and structure to that of the Par Pond population during 1972-1978. 
METHODS

Par Pond is an 1120 ha cooling reservoir located on the Department of Energy's Savannah River Site in Barnwell County, South Carolina (Gibbons and Sharitz 1981). Par Pond was created in 1958 by the impoundment of Corley Mill Pond and Lower Three Runs Creek, a tributary of the Savannah River. Both areas had resident populations of alligators that were probably the source for the current population. Thermal effluent from R-reactor was discharged into the North Arm of Par Pond via Pond B from 1961-1964 and into the Hot Arm via Pond C from 1959 to the present. Temperature and duration of thermal discharge into the Hot Arm vary from year to year due to changes in reactor operations, with temperatures in the Hot Arm averaging 3-12 C above ambient when the reactor is operating at full power. Periods of low or no discharge may last from a few days to several months. During this study (May 1986-March 1989) the reactor was only operational from May 1986-August 1987. Approximately $10 \%$ of Par Pond is affected by thermal effluent; the remaining $90 \%$ acts as a warm monomictic lake. Most of Par Pond's $53 \mathrm{~km}$ of shoreline is bordered by aquatic vegetation including Typha latifolia, Typha domingensis, Scirpus cyperinus, Nelumbo lutea, and Nymphaea odorata (Parker et al 1973). In addition to the alligator there are 5 species of turtles, 28-30 species of fish, a large number of waterfowl and wading birds (Sharitz and Gibbons 1981), and numerous macroinvertebrates (Thorp and Bergey 1981) that occur in and 
and around Par Pond.

Alligators $\leq 1.25 \mathrm{~m}$ were captured at night by hand from an airboat. Animals $>1.25 \mathrm{~m}$ were captured using a self locking wire noose attached to PVC pipe, or by baited trip snares (see below). Total length (TL), snout-vent length (SVL), skull length (SKL), skull width (SKW), sex and mass were recorded for each animal. All animals were given an individual mark by clipping scutes. Animals $>1.5 \mathrm{~m}$ were fitted with color coded collars and either red (male) or yellow (female) numbered cattle ear tags.

Captures of animals $\leq 1.25 \mathrm{~m}$ were classified as pre-census, prior to october 1987, and then by capture period (period 1--October 1987, period 2--July 1987, period 3--March 1988, period 4--July 1988). Capture periods (except for period 1, 1 night only) consisted of 3 consecutive nights of capturing animals. Attempts were made to capture animals of all sizes; however, most animals captured were less than $1.25 \mathrm{~m}$. All of Par Pond was searched during each capture period, and alligators captured on nights 1 and 2 were held until the third night when all animals were released.

Baited trip snares (Murphy and Fendley 1973; Murphy and Fuller 1982) were set during three separate trapping periods, september and October 1987 (162 trap nights), April and May 1988 (282 trap nights) and september 1988 (75 trap nights). Traps were set throughout Par Pond in locations where animals had been observed during night counts. Traps 
were baited with fish or chicken and checked once a day (early morning), and mammal traps set on shore near the traps to minimize raccoons stealing the bait.

To calculate the number of alligators $>1.5 \mathrm{~m}$, aerial surveys were conducted around the entire perimeter of Par Pond once each month (March-July 1988 and october 1988). Hughes $300 \mathrm{C}$ helicopter with one observer and a pilot was used. All surveys were flown at 10-25 m and 20-30 knots between 0900 and 1600 and lasted approximately $1.5 \mathrm{hr}$. Location, size of animals, and presence of collar were recorded. Animals were counted as "marked" if they had a collar.

Jolly-Seber population estimates (Jolly 1965; Seber 1965) for animals $\leq 1.25 \mathrm{~m}$ were calculated using program JOLLY ( $\mathrm{J}$. Hines Putuxant Wildl. Res. Lab computer program). The Jolly-Seber estimator allows for time specific capture probabilities, death, and immigration. Because of the potentially high mortality rate for hatchling alligators over the course of two years, a closed population estimator was inappropriate for this size class. However, the adult population is essentially closed so the Lincoln-Peterson estimator was used to calculate the number of animals $>1.5$ m.

Data from night counts conducted during this study (Chapter Two) and data from previous studies (Bara, 1971, 1972, 1973, 1974; Murphy 1981) were used to calculate the average annual exponential rate of increase by regressing 
the natural $\log$ of alligators/ $\mathrm{km}$ against year. 
RESULTS

Model A of the JOLLY program, which allows for death but no immigration, was determined to be an appropriate model for estimating the number of alligators $\leq 1.25 \mathrm{~m}$. Population estimates and confidence intervals are presented in Table 1. The number of alligators $>1.5 \mathrm{~m}$ estimated using the Lincoln-Peterson estimator varied from 94 in July 1987 to 242 in June 1988 (Table 1). An overall population estimate of 197 alligators was calculated by combining the mean value from the aerial surveys with the March 1988 Lincoln-Peterson estimate and adding 6 animals between 1.25 and $1.5 \mathrm{~m}$ which were not counted in either estimate.

Trapping success ranged from 5-15 \%. Thirty-nine animals ranging in size from 1.5 to $3.85 \mathrm{~m}$ were captured during 519 trap nights. The sex ratio of animals trapped in the spring was not different than the sex ratio of animals trapped in the fall (4:1, males:females).

A total of 183 different non-hatchling and 157 hatchling alligators were captured from May 1986-October 1988. Of the non-hatchlings, 41 (19\%) were adults (>1.8 m) and 142 (81\%) were juveniles. This is not different from adult to juvenile ratios reported by wilkinson (1983) for a coastal South Carolina population or by Chabreck (1966) for a Louisiana marsh population ( $16 \%$ adult, $84 \%$ juvenile for both). The distribution by size class was significantly different from that found by Murphy (1977) for the same 
Table 1. Jolly-Seber estimates based on captures for alligators $\leq 1.25 \mathrm{~m}$ and Lincoln-Peterson population estimates for alligators $\geq 1.5 \mathrm{~m}$ based on aerial survey data.

Month

$\leq 1.25 \mathrm{~m}$

October 1986

July 1987

March 1988

$\geq 1.5 \mathrm{~m}$

April 1988

May 1988

June 1988

July 1988

October 1988

Weighted mean
Estimate

$95 \%$ confidence interval
123

87

83

122

100

242

94

117

108
93-153

$64-110$

45-121

$77-167$

65-135

$0-485$

22-166

$11-223$

$97-120$ 
population in 1972-1976 (Figure 1; G-Test, G=222.058, d.f. $=2,6, p<0.001$ ) and different than that reported by Chabreck (1966) for a population inhabiting coastal marsh in Louisiana (G-Test, $G=75.84, \mathrm{~d} . \mathrm{f} .=2,6, \mathrm{p}<0.001$ ).

The overall sex ratio was $2.6: 1$ (Figure 2 ). There was no difference between the juvenile and adult sex ratios (Table 2) or between the current adult sex ratio and that reported by Murphy (1977).

Sixteen nests or pods of young were found from 1985-1988. Based on nest and pod locations this represents the reproductive output of at least 8 females and an average of 4.0 nests per year. The number of nests and hatchlings located varied greatly from 0 nests and hatchlings in 1986 to 8 nests and 152 hatchlings in 1988 .

The average annual exponential rate of increase was 0.06 and was significantly different from zero $(F=48.73$, d.f.=1,9, p<0.0001; Figure 3). 
11 
䍂

م

อ

เே

$\infty$

an

I $n$

م

$\infty$

$\infty$ प

담

요.

थ 4

420

艺

م $\Rightarrow$

욱

$\stackrel{2}{\infty}$

ผ $\omega$

เ

$\checkmark 5$

$\rightarrow 1$

吕

$6 \mathrm{H}$

a ?

雚占

물

政

-

$\omega$

0

고

U

$\Omega$

'

.

อ

5

"艹 


\section{3}


?

น

อ ก

ص

$\infty$

in

苗

$\infty$

- 0

员

O

$\stackrel{\infty}{\omega}$

5
0
5
1
5
0
1
0
5
$\vdots$
5
5
0

卢

$\Omega$

움

莫

(1)

5

货 


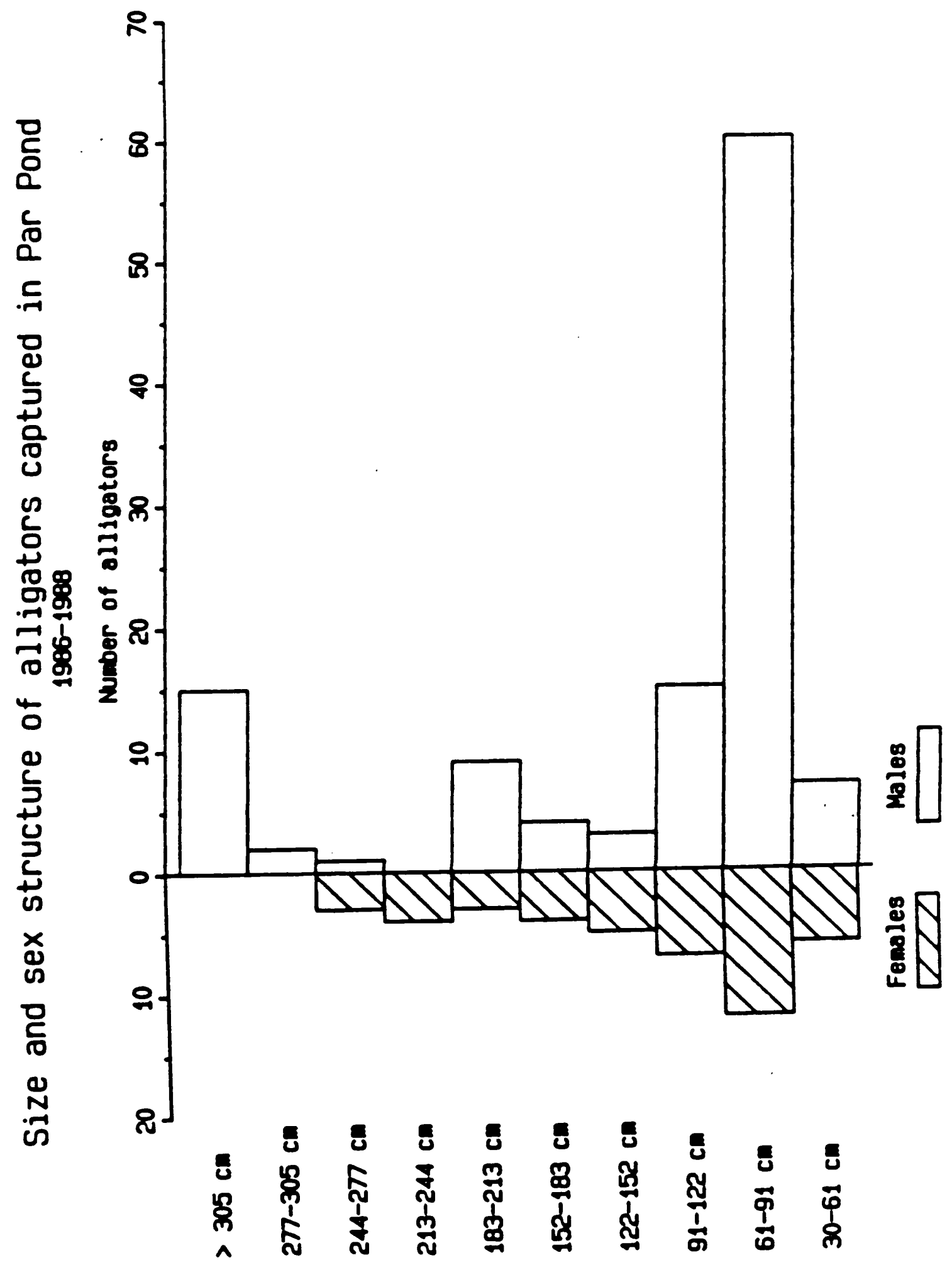


Table 2. Estimated population size and sex ratios for alligators inhabiting Par Pond in 1972-1974 and 1986-1988. 1974 data are from Murphy 1977. 1988 total population size includes 6 animals 1.25-1.5 $\mathrm{m}$ that were captured but not represented in either estimate.

Year

Population estimate sex ratio and confidence interval (method)

1974 Adults

$70 \quad 29-143$ (Lincoln)

$3.7: 1$

1974 Juveniles

$40 \quad 19-72$ (Lincoln)

$1.8: 1$

1974 Total

110 48-215 (Lincoln)

$3.2: 1$

1988 Adults

$10897-120$ (Lincoln)

$2 \cdot 5: 1$

1988 Juveniles

83 45-121 (Jolly)

$3.1: 1$

1988

Total

197

$2 \cdot 6: 1$ 
م.

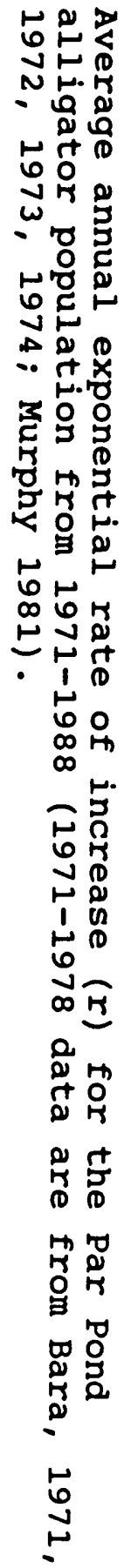




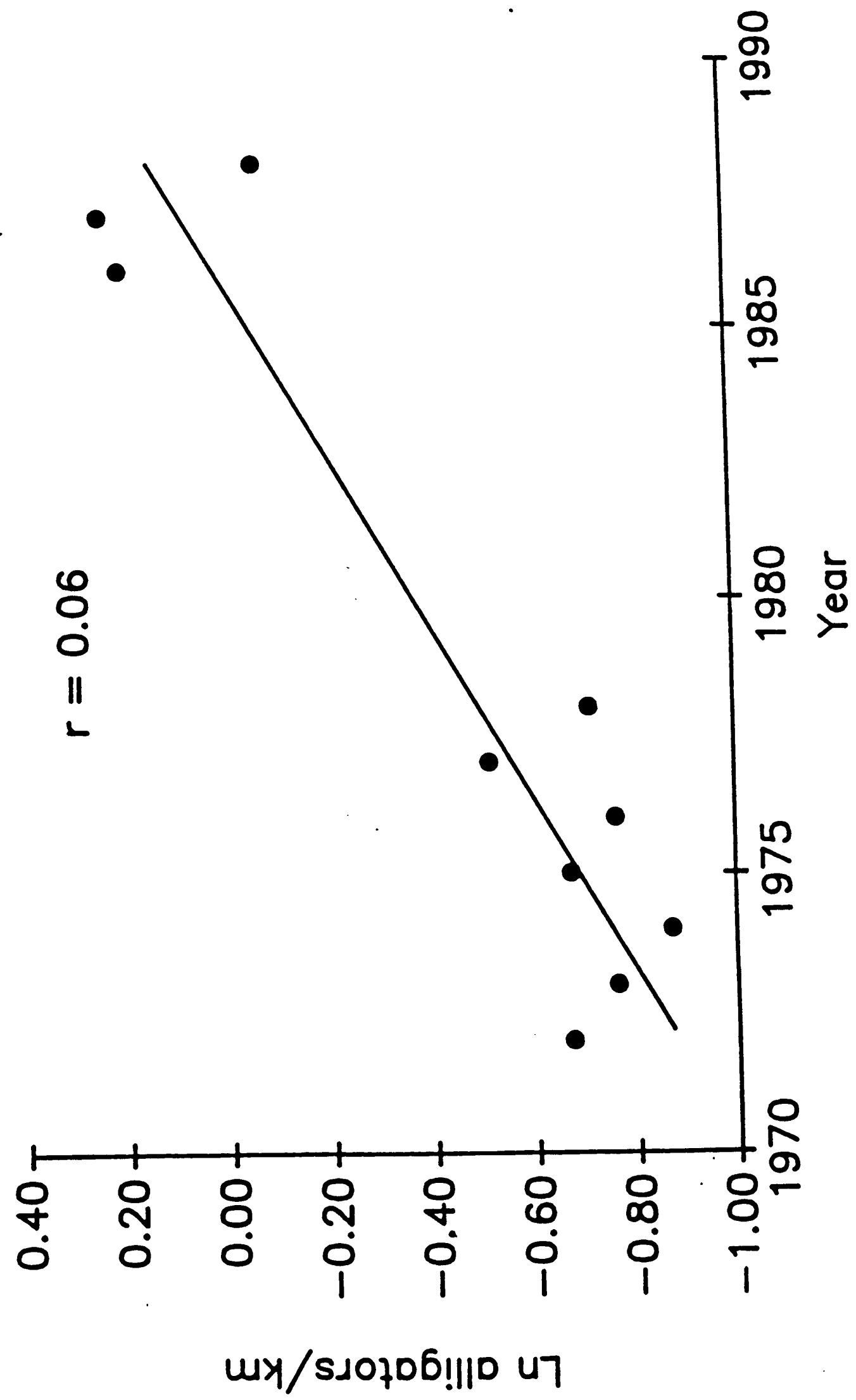




\section{DISCUSSION}

That the number of alligators inhabiting Par Pond has nearly doubled in the last 14 years is shown by both capture data and night counts. Counts show an average yearly increase of $6 \%$. Similar rates of change $(5-7 \%)$ have been reported for populations of crocodylus porosus recovering from uncontrolled hunting in the Northern Territory of Australia (Bayliss 1987). In addition, the structure of the population has changed from one dominated by large adults to a population with a high proportion of juveniles. The increase in the number of alligators and the shift in the size distribution is what would be expected for a colonizing population. Par Pond is now 30 years old. The alligators that originally colonized the reservoir were probably adults inhabiting the creeks and ponds that were dammed to create the reservoir, and subadults that moved in from surrounding areas. Initially there were probably only a few mature females, which may not have nested every year. In 1974 there were approximately 15 adult females (Murphy 1977), and currently there are approximately 24, indicating that despite what appeared to be low reproduction in the mid-1970s (Murphy 1977), the extent of reproduction over the last 14 years has been adequate to increase the adult population. Alligators have a large clutch size (30-60 eggs), and over a females reproductive life she only needs to produce one daughter and one son that survive to reproductive size for the population size to remain 
constant. The survival of additional animals will result in an increase in the population. Graham (1968) stated that, theoretically, hatchling mortality could reach 998 and a crocodile population could still be stable.

The extent of reproduction is variable between years, and individual females in this population appear to be nesting every other year and in some cases every third year, with approximately $33 \%$ of the estimated number of mature females nesting in 1988. This is slightly higher than the percentage of females reported to nest each year in coastal South Carolina (27.5\%, Wilkinson 1983), slightly lower than that found in north Florida (37\%, A. R. Woodward and M. F. Delany, FL Game and Fish Comm. Alligator research report, 1987), and about half the rate reported from Louisiana (68\%, Walthers and Ivy 1964 in Chabreck 1966; Joanen and McNease 1975) .

Both the percentage of females nesting and the nesting interval will affect the population growth rate. However, since the number of years a female is reproductively active is high (15 years, Ferguson 1983), one bad reproductive year every few years should not substantially affect the long-term population recruitment. These bad reproductive years, whether the result of few females nesting, high rate of nest loss through predation, flooding or desiccation, or unfavorable climatic conditions for hatchlings, will result in gaps in the number of individuals in the smaller size classes. Variation in growth rates of individuals hatched 
immediately before and after the bad year will mask the effect in the larger size classes so there should not be corresponding gaps in the number of potentially reproductive animals.

In this population, there is a gap in the number of males, between 213 and $305 \mathrm{~cm}$. This is not unusual, because subadult and small adult males are at risk from aggressive interactions with large adults and probably retreat to inaccessible areas where they are not captured, or leave the pond until they are large enough to be successful in encounters with large males. This pattern has been observed in Crocodylus porosus in Australia (Messel and Vorliceck 1986)

The skewed sex ratio observed in the current population is not different from that reported by Murphy (1977) and does not seem to be unusual for alligator populations. Nichols and Chabreck (1980) reviewed data from wild populations in LA and found 11 of 14 populations to have sex ratios biased toward males. Wilkinson (1983) reported a 60:40 male-biased sex ratio for populations in coastal south Carolina from 1979-1983, and Fuller (1981) reported the same ratio for both juveniles and adults in Lake Ellis simon in North Carolina. It is possible that the bias toward males in the adult population is a result of capture technique rather than a true indication of the animals utilizing Par Pond. Males are known to favor open water habitats (Joanen and McNease 1972) and females marsh or swamp habitats 
(Joanen and McNease 1970). Males favoring the more open areas would be more likely to have been trapped in my study, as traps could not be set equally in open water and marshy habitats. The June aerial survey data also indicate the presence of animals which may be untrappable and unsightable during the rest of the year because of a preference for more secluded areas (i.e., females inhabiting the back portions of coves).

Alligators $<1 \mathrm{~m}$ do not seem to be segregated by sex, but rather stay together in pods. Thus, the juvenile sex ratio is probably not biased by capture technique. The juvenile sex ratio was not different from the adult sex ratio, indicating that either more males are produced (as a result of nest temperatures $>33 \mathrm{C}$, Ferguson and Joanen 1982) or that females suffer higher mortality than males, particularly during the first year. The observed juvenile sex ratio is more likely to be a result of the former since males produced at high temperatures are smaller than females produced at low temperatures (Ferguson and Joanen 1982) and smaller animals, unless they have faster growth rates, would be susceptible to predation or mortality for a longer time. This would result in a female biased population rather than the observed male biased population.

Based on the current population structure and the rate of increase over the last 14 years (despite what seemed to be a stable or declining population in the 1970s) the number of alligators in Par Pond should continue to increase to an 
estimated 237 individuals by 1993 and 322 alligators by 1998 . 


\section{CHAPTER TWO}

AERIAL SURVEYS, NIGHT COUNTS, AND MARK-RECAPTURE;

A COMPARISON OF THREE TECHNIQUES FOR ESTIMATING ALLIGATOR POPULATION SIZE.

\section{INTRODUCTION}

Interest in the conservation and use of crocodilians as a renewable resource has increased over the last 15 years (Joanen and McNease 1981; Webb et al 1987). In order to effectively utilize this resource, appropriate management plans must be established. The first step in establishing a successful management plan is to determine the extent and distribution of the resource. For crocodilians, this includes determination of numbers and size structure of the population. To do this reliable censusing techniques must be used, which for crocodilian populations include night eyeshine counts, mark-recapture techniques, and basking/aerial surveys (Chabreck 1966; Thompson and Giddon 1972; Magnusson et al 1978; Magnusson 1982; Wood et al 1985; Bayliss 1987). In some cases data from one type of survey need to be compared to data from one of the other methods, to do this the relationship between the indices must be known.

Night eyeshine counts are probably the most common means of censusing crocodilian populations because of the relative ease by which they can be conducted. The tapetum of a crocodilian's eye reflects yellow-orange to bright red when hit with a spotlight and can easily be seen from distances of 50-100 $\mathrm{m}$ and under some circumstances even further. If 
biases to visibility, including vegetation, time of year, and weather conditions are taken into account, and the surveys are standardized (Chabreck 1966; Woodward and Marion 1978; Taylor and Neal 1984) night counts can yield estimates of crocodilian numbers that are comparable among surveys. Night counts have been estimated to reveal 20-25\% of the animals present under good conditions (Taylor and Neal 1984). If the actual number of alligators present needs to be known, as for calculating sustained yield (Bayliss 1987), the percentage seen during a particular count must be, in some way, correlated to population size. The number of alligators seen during a particular count has been shown to be positively correlated with water temperature, (Murphy 1977; Woodward and Marion 1978). However, the slope of the regression line of number seen relative to temperature may depend on the size distribution of the population (Woodward and Marion 1978).

Aerial surveys have been used in determining crocodilian abundances in remote areas inaccessible by boat (Graham 1968; Parker and Watson 1970; Bayliss et al 1986). The use of aerial surveys may in some cases be more convenient and cost effective (Bayliss 1987) than other survey methods. As with night counts, there are several problems with aerial surveys. They cannot be conducted successfully in areas of tall vegetation, especially forested areas, and they are biased against small animals (Parker and Watson 1970). Factors such as observer-bias, weather conditions and flight 
altitude and speed all affect counts (Caughley 1974; Grigg 1979). In addition, they may represent only a small portion of the population (Graham 1968; Parker and Watson 1970). As with night eyeshine counts, if more than relative numbers are needed, appropriate correction factors must be applied to the counts.

A third, but the most time consuming, method of evaluating population size is through the use of . mark-recapture techniques. Population estimates are not free from bias but, if care is taken in meeting the assumptions, they can provide reasonable estimates of the population size. In many cases, mark-recapture studies are not possible because of financial, logistical, or man-power constraints. By combining data from population estimates with the other indices of abundance, a better understanding of the relationship between the index and "true" number of alligators can be achieved.

The purpose of this study was to estimate the size and structure of the alligator population in Par Pond, Savannah River site, near Aiken, SC using these three methods; compare the three techniques, and to evaluate the use of aerial surveys and night counts as an index of alligator population size. 
METHODS

Par Pond is an 1120 ha cooling reservoir located on the Department of Energy's Savannah River Site in Barnwell County, South Carolina (Gibbons and Sharitz 1981). Par Pond was created in 1958 by the impoundment of Corley Mill Pond and Lower Three Runs Creek, a tributary of the Savannah River. Both areas had resident populations of alligators that were probably the source for the current population. Thermal effluent from $R$-reactor was discharged into the North Arm of Par Pond via Pond B from 1961-1964 and into the Hot Arm via Pond C from 1959 to the present. Temperature and duration of thermal discharge into the Hot Arm vary from year to year due to changes in reactor operations, with temperatures in the Hot arm average 3-12 C above ambient when the reactor is operating at full power. Periods of low or no discharge may last from a few days to several months. During this study (May 1986-March 1989) the reactor was only operational from May 1986-August 1987. Approximately $10 \%$ of Par Pond is affected by thermal effluent, the remaining $90 \%$ acts as a warm monomictic lake. Most of Par Pond's $53 \mathrm{~km}$ of shoreline is bordered by aquatic vegetation including Typha latifolia, Typha domingensis, Scirpus cyperinus, Nelumbo lutea, and Nymphaea odorata (Parker et al 1973). In addition to the alligator there are 5 species of turtles, 28-30 species of fish, a large number of waterfowl and wading birds (Sharitz and Gibbons 1981), and numerous macrocinvertebrates (Thorp and Bergey 1981) 
that occur in and around Par Pond.

Alligators were captured at night by hand or with a wire noose, or trapped by baited trip snares (Murphy and Fendley 1973). All animals were measured (snout-vent length (SVL), total length (TL), weight, skull length and width (SKL and $\mathrm{SKW})$ ) and marked. Alligators $\geq 1.5 \mathrm{~m}$ were fitted with colored collars for identification during aerial surveys. Population estimates were calculated from a combination of mark-recapture and mark-resighting data collected from October 1986-October 1988 (Chapter One).

Night-time eyeshine counts were conducted on three consecutive nights each month from July 1987 through August 1988. Each survey started one half hour after sunset during the last quarter of the moon (to minimize the possible effect of moonlight during the surveys). An airboat equipped with a 200,000 candlepower Q-beam was used for all surveys. Surveys were conducted by one driver and two observers. The observers took turns shining to minimize fatigue. A standardized route with five temperature stations was surveyed each night (Figure 4). Location and size estimate (when possible) of each animal was recorded, in addition general weather conditions (cloud cover, wind, wave action) and air and water temperatures were recorded at the beginning of each survey. Surveys were conducted on nights when winds were $<5 \mathrm{mph}$ to minimize the effects of 


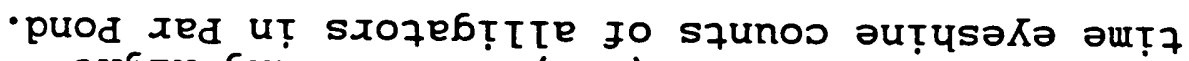

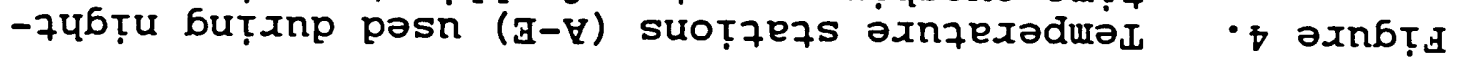




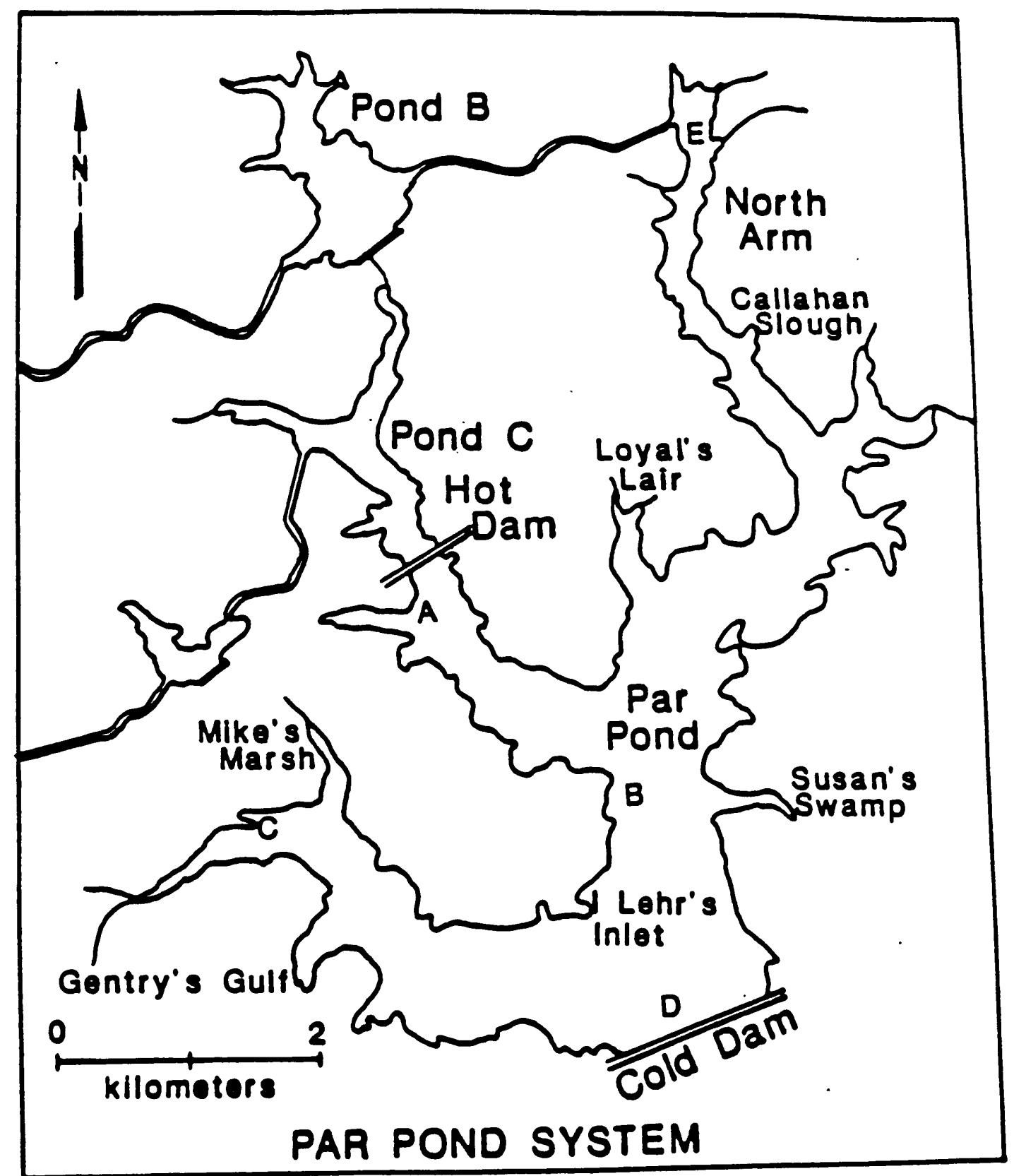


wind and wave action on the number of alligators sighted. Aerial surveys were conducted around the entire perimeter $(53 \mathrm{~km})$ of Par Pond once a month from October 1987 to October 1988. A Hughes $300 \mathrm{C}$ helicopter with one observer and a pilot was used. All surveys were flown at 10-25 m and 20-30 knots between 1100 and 1400 and lasted approximately $1.5 \mathrm{hr}$. Survey dates corresponded to days when night surveys were conducted. Location, size of animals and presence of collar were recorded. General weather conditions were noted.

The relationship between estimated size and true size of alligators seen during night counts was determined by first estimating the size of the alligator to the nearest $0.25 \mathrm{~m}$ (all size estimates were made by $\mathrm{L}$. Brandt), and then capturing the animal and measuring SVL, TL, SKL, and SKW. Data for 50 alligators ranging in size from $50 \mathrm{~cm}$ to $384 \mathrm{~cm}$ were collected in this manner. To determine the relationship between the size estimates made during aerial surveys and the actual size of the alligators, size estimates of 15 individually identifiable animals (based on collar color and tag number) were compared to total length data collected prior to the aerial survey. 
RESULTS

A total population estimate of 197 alligators $(89<1.5$ $\mathrm{m}$ and $108 \geq 1.5 \mathrm{~m}$ ) was obtained by combining estimates made for adults (Lincoln-Peterson estimator) and juveniles (Jolly-seber estimator, see Chapter one for details). The size distribution of the population (based on actual captures) has changed significantly from one with a high proportion of adults (Murphy 1977) to one which is dominated by juveniles.

Night-time eyeshine counts showed a great deal of variation by month ranging from 0 in January to a mean of 78.5 in May. The mean number of alligators sighted was significantly higher than surveys of the same population in 1972-1973 (Figure 5, Paired t-test, $t=-2.708, d . f .=10$, $0.01<\mathrm{p}<0.05)$. There was a positive linear correlation between the number of alligators counted and the mean water temperature $\left(r^{2}=0.80, F=122.045, d . f .=1,31, p<0.001\right.$, Figure 6). The correlation was slightly lower than that found by Murphy $\left(r^{2}=0.88,1977\right)$ and a quadratic equation fit the data better than the linear relationship $\left(r^{2}=0.84, F=79.66\right.$, d.f. $=2,30, p<0.001$, Figure 6).

Eyeshine counts ranged from 0 to 41.1 of the total estimated population. A comparison of the predicted value from the quadratic regression equation with population estimates indicated that $29.3 \%$ of the total population was observed at $25 \mathrm{C}$ and $34.4 \%$ at $30 \mathrm{c}$. These values are similar to those obtained using the linear relationship 
(26.3 and 34.8 respectively) and similar to the findings of Murphy (1977). 

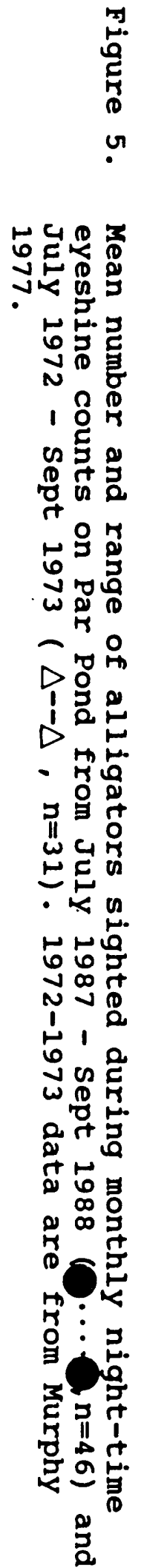

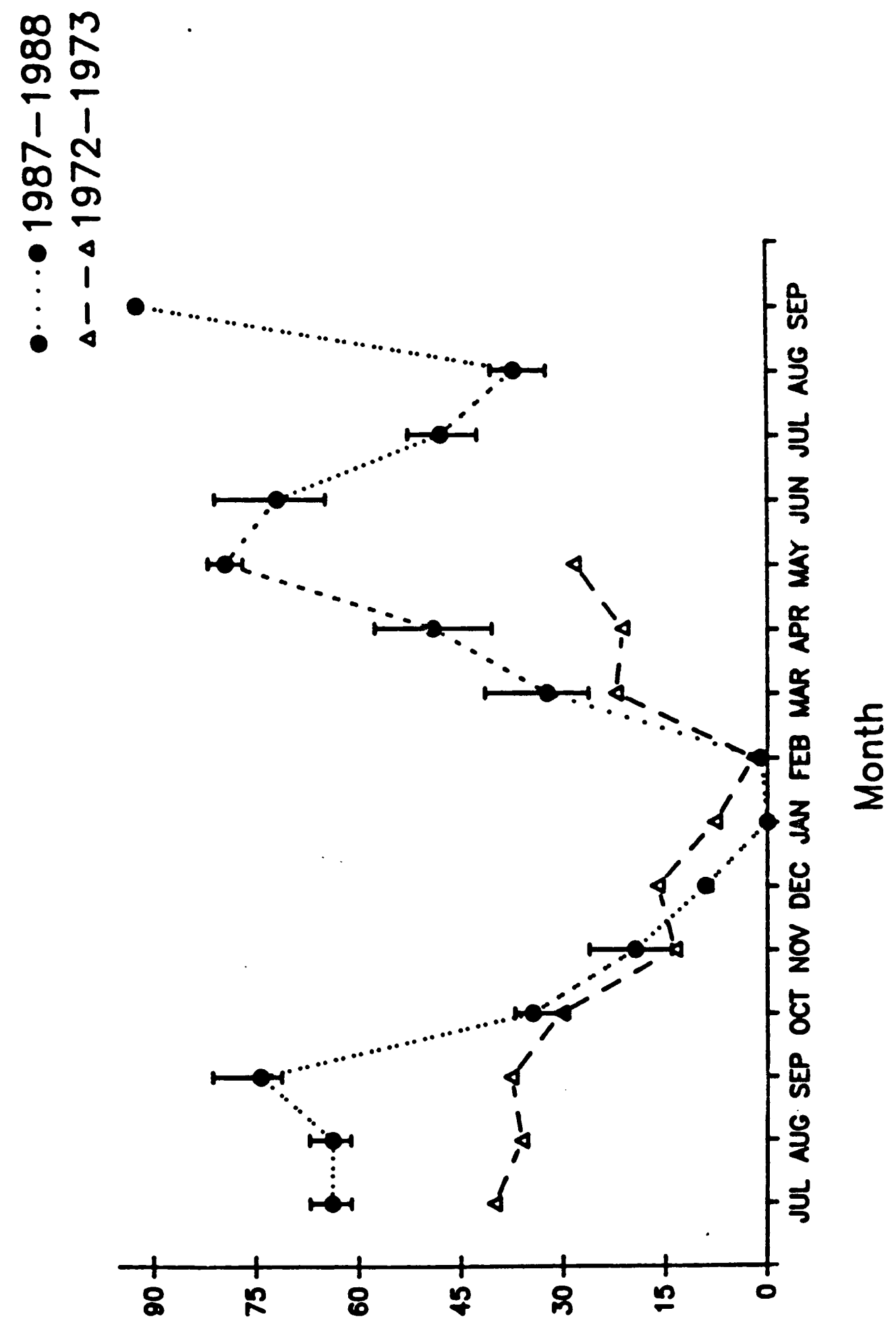

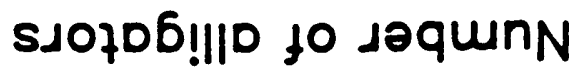


式

ס

员思

H. D

ปั

5 马

อ.

它告

n $\sigma$

C

दू

$<0$

ก

임

5 틈

क

R

OO

อ

क

مै

$\exists$

40

Ev

$\leftarrow$

$\mapsto 8$

$\infty 5$

$\checkmark$ t

10

48

它写

1 ํㅗ

0 t

$\infty$

龺

공

山

N

(

草

(1) 


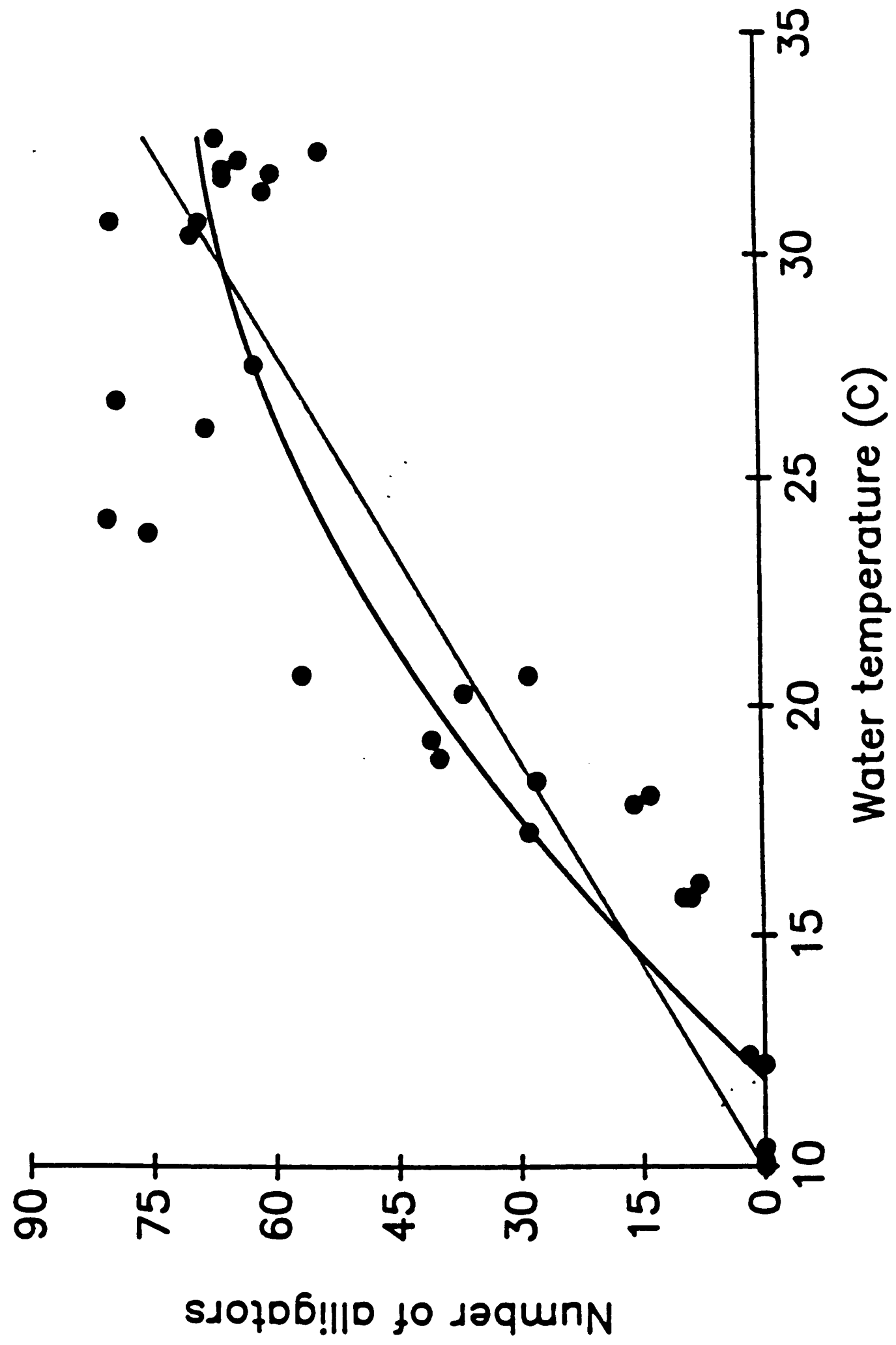


Only $40.7 \%$ (range $10 \%-59 \%$ ) of the animals seen in all night surveys were approached close enough to make size estimates. Of these, $59.7 \%$ (range $0-85 \%$ ) were $<1 \mathrm{~m}$. The percentage of alligators for which size estimates were possible was greater during the July-October 1987 surveys $(49.7$ 8) than during the Mar-July 1988 surveys (25.0 \%). The percentage of animals identified that were $<1 \mathrm{~m}$ was not appreciably different during the two time periods (69 8 , $1987 ; 71 \%, 1988)$.

There was a strong positive correlation between estimated size during night surveys and real size $\left(r^{2}=0.991\right.$, d.f.=1,49, p<0.001). Animals $<1 \mathrm{~m}$ were both over and underestimated, while those between 1 and $2 \mathrm{~m}$ were almost always over-estimated, and those $>3.5 \mathrm{~m}$ were underestimated (Figure 7). Most of the errors in estimates were less than $0.25 \mathrm{~m}$. Size estimates from aerial surveys also showed a high correlation to real size $\left(r^{2}=0.972, d . f .=1,14, p<0.001\right)$ though there was greater variability in the magnitude of the difference between real size and estimated size. Counts from aerial surveys were highest in the spring and lowest in the fall and winter (Figure 8). Counts from March to october were negatively correlated with water temperature ( $r$ $=-0.90, \mathrm{~d} . f .=1,9, \mathrm{p}<0.001)$. Counts ranged from 0.5 \& to 66.7 of the estimated population size and $0.9 \%$ to $66.7 \%$ of the adult population size. $37.2 \%$ of the animals observed during aerial surveys were larger than 


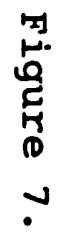

임

号

‥ D

농

๑

(⿻)

․․․

ס

-

o

돈

द

电

ก

$3 \stackrel{0}{1}$

iI .

药

$-\pi$

(1)

约

$\checkmark$ N

ㄷ. 1

0

뭉

ก

D

+

n

H.

II

Go

$\because \rightarrow$

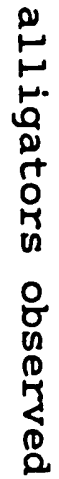




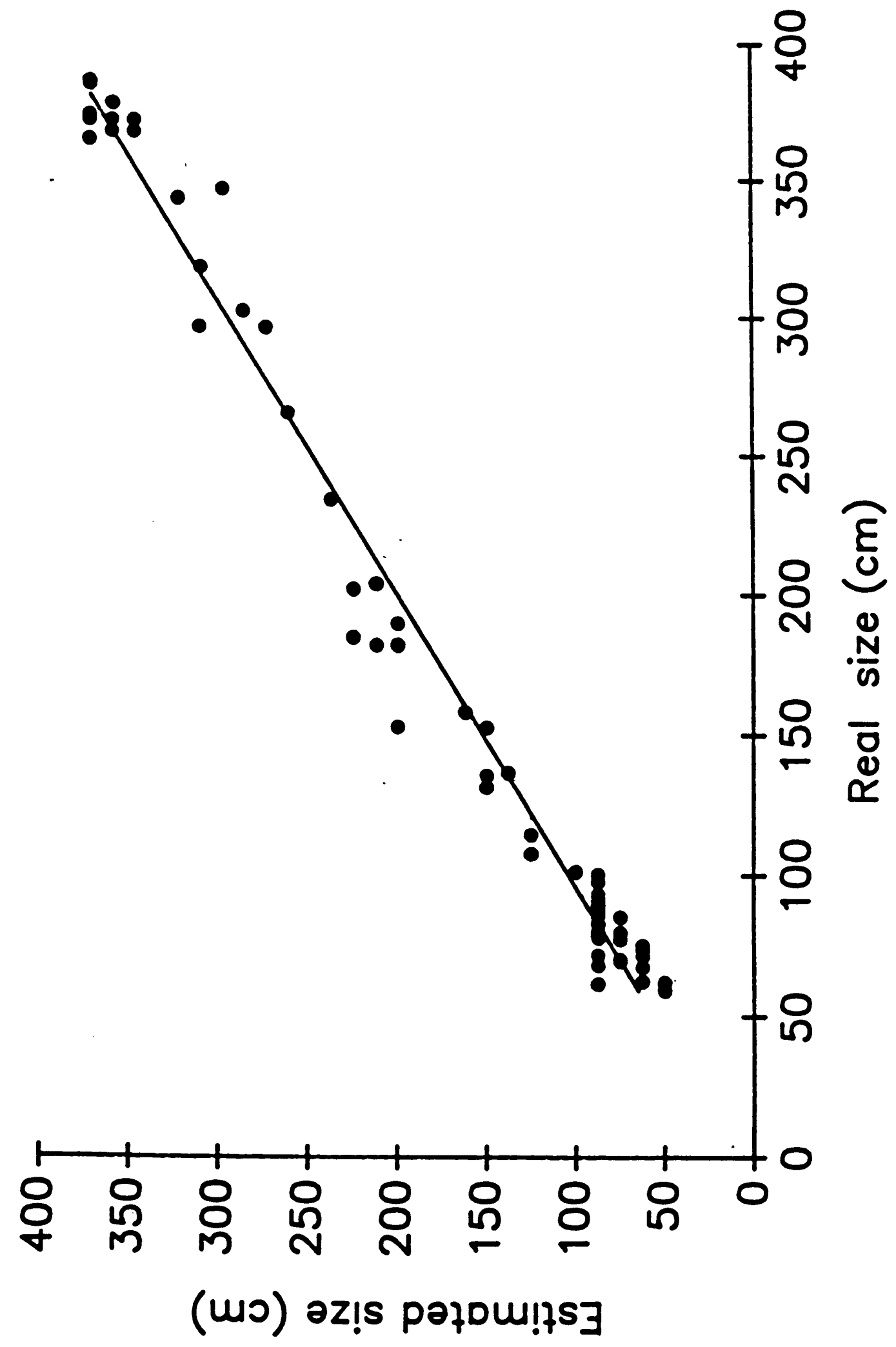




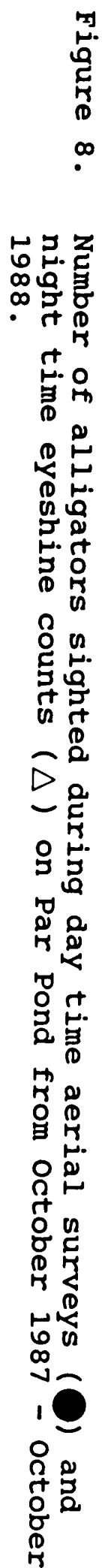


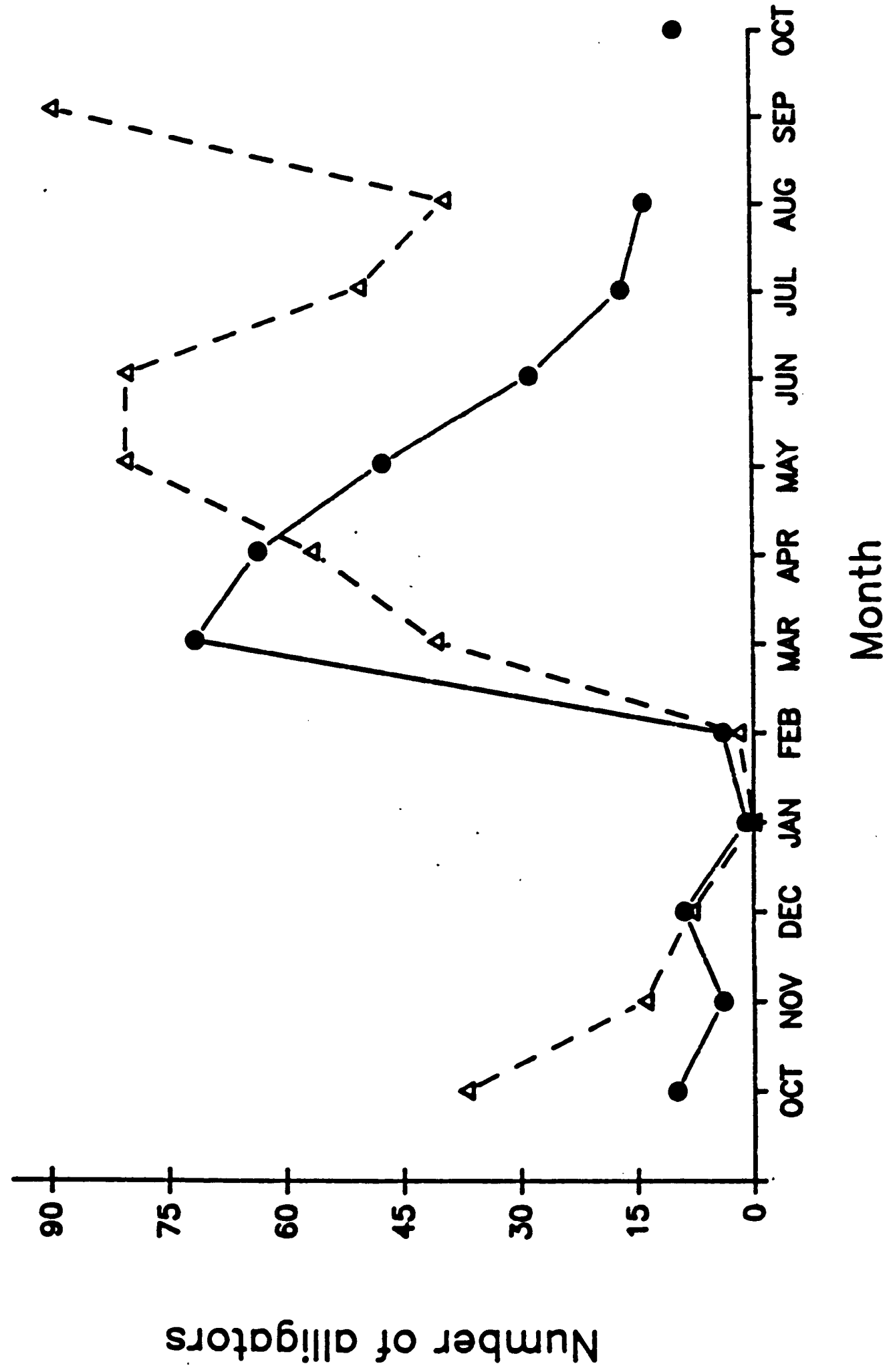


$3.0 \mathrm{~m}, 54.3 \%$ were between 2.0 and $3.0 \mathrm{~m}, 8.2 \%$ were 1 to 2 $\mathrm{m}$ and only $0.4 \%<1 \mathrm{~m}$. The size distribution of animals sighted varied by month and the overall distribution was significantly different than the size distribution of captures (Figure 9; G-test, G=80.316, d.f. $=2,5, \mathrm{p}<0.01$ ). The relationship between the number of animals $>1 \mathrm{~m}$ observed in aerial surveys and night counts was curvilinear (Figure 10) with a regression equation of $\mathrm{N}=-1.770+2.383(\mathrm{~A})-$ $0.027\left(A^{2}\right)$ where $A=$ the number seen during the aerial survey, and $\mathrm{N}=$ the number estimated for the night count conducted on the same day $\left(r^{2}=0.896, F=30.198\right.$, d. $f .=2,7$, $\mathrm{p}<0.0001)$. 
田.

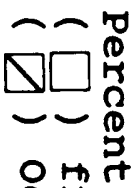

ก

$+0 \Omega$

의응

0 음

군

누요.

舟

a 40

160

$0 \infty \mathrm{A}$

$\Omega v$

ค 10

吃

(1)

$\sigma$

0
त

$6 \pi$

$\infty$ 光

文

II

$\stackrel{\Delta}{*}$

GN $N$

- $6 \exists$

on 0

‥ $\sigma$

는

?

त

58

ט

- $\frac{0}{K}$

م

告 


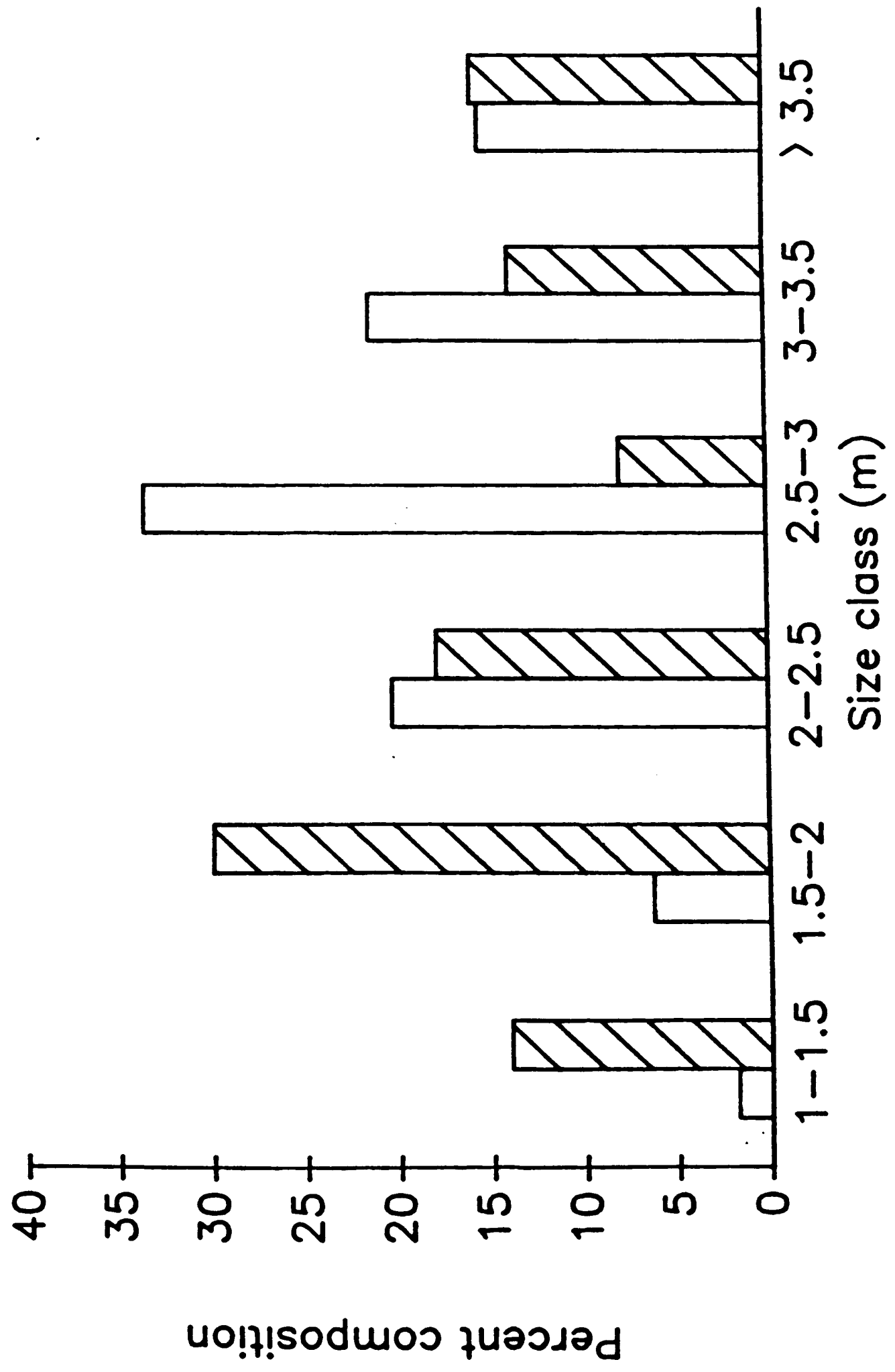


勿

'0

임

노

$\infty$ U

a 2 ?

ऽ 告

II

○员

- 18

ه

O n

은

뉴

o

옳

م

등

常

$\rightarrow$

計

刍

웅

+

의

D $V$

$\mapsto$

63

尚 0

1

串

त

当

ס

跂

노.

$\infty_{\infty}^{\infty} \frac{0}{2}$ 


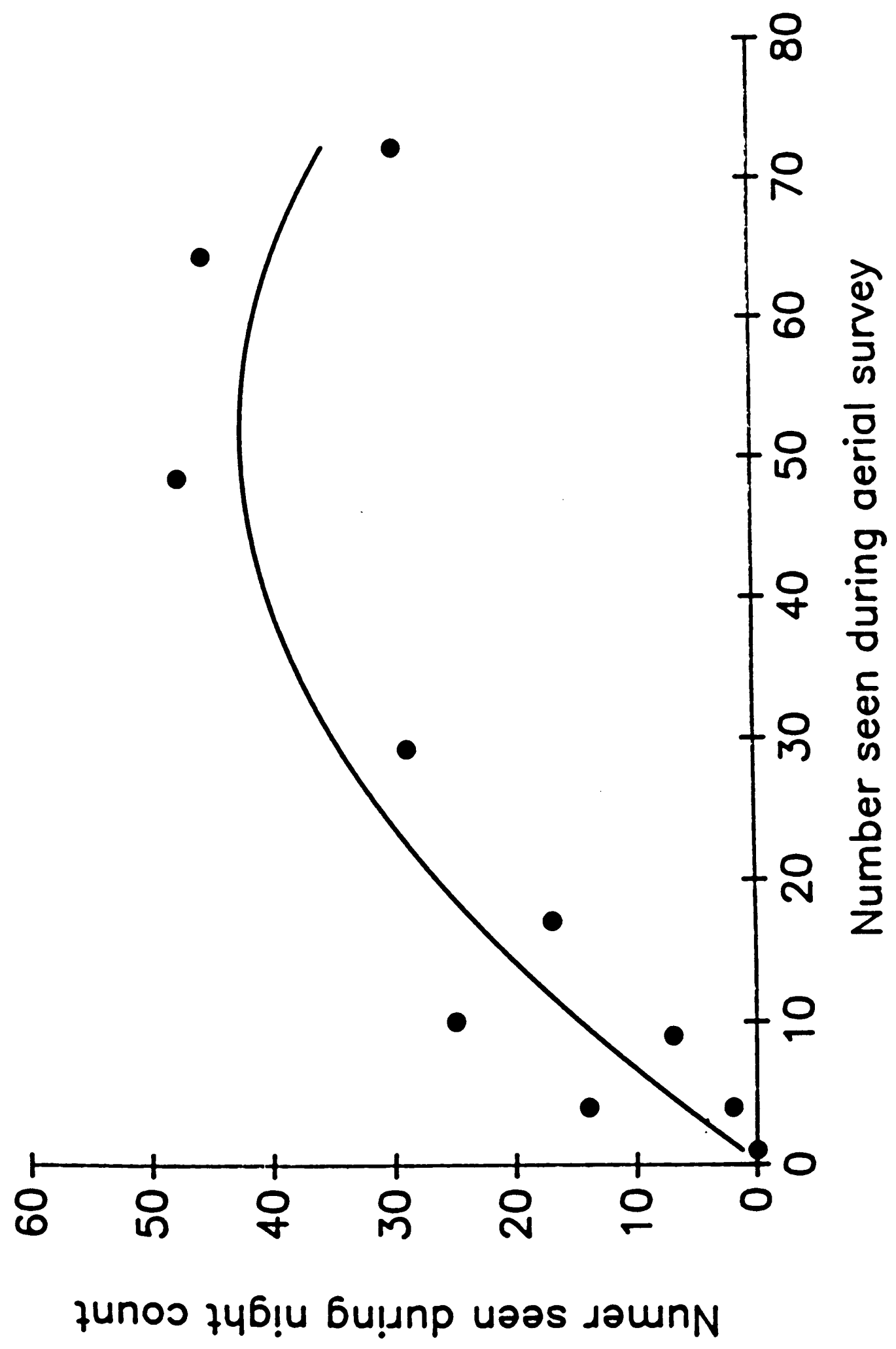




\section{DISCUSSION}

Data collected here indicate that for this population aerial surveys (when corrected for biases against small animals) are a useful technique for obtaining an index of alligator population size, and when combined with a marking study can be used to estimate the adult population size.

The relationship between night counts and aerial surveys can be described by a second order regression equation. This relationship is different from that determined for Crocodylus niloticus populations in Kenya (Graham 1968) and in Uganda, (Parker and Watson 1970) (both single value correction factors) and by Bayliss (1987) for c. porosus in Australia ( 3 linear equations for different time of year and habitat) indicating that the relationship varies with habitat and species. Extreme care should also be taken in applying this relationship to other habitats and populations without verification.

Counts from aerial surveys are consistently high in the spring (Seigel et al 1986) when air temperature is consistently above water temperature. Counts decline during the summer. Night counts follow a similar trend with an initial time lag, as a result of the time it takes the water temperature to increase. As the water temperature continues to increase the number of alligators observed during aerial surveys decreases. The decrease in the number of alligators observed during the late spring and summer aerial surveys is probably due to three factors: 1. The amount of time the 
animals spend basking (the animals most easily observed during aerial surveys are ones that are basking). During the spring the water is cooler than the air so the alligators spend more time basking, and are therefore more likely to be seen during a survey. As the water temperature increases through the spring and summer the alligators need to spend less time basking (Spotilia 1974; Lang 1987) and are less likely to be observed. 2. An increase in the amount of aquatic vegetation which increases the probability of not seeing an animal which is really there. 3. Nesting females becoming less visible because of their movement out of the main portion of the pond to more secluded nesting sites. The latter two factors probably also affect the number of alligators observed during night counts. Because of the effects of season, water temperature and aquatic vegetation on the number of alligators observed, aerial surveys should be conducted in the early spring to minimize the effects of these factors on the number of alligators observed. Surveys conducted under similar conditions over a number of years could than be used as an index of the minimum size of the adult population.

If an estimate of the adult population size is needed, aerial surveys can be combined with marking studies. The use of aerial surveys to "sight recapture" animals would be particularly useful in situations where animals are unlikely to be captured physically a second time, or when man-power is limited. 
While aerial surveys seem to be useful for estimating the adult population size, they are not good for determining the adult size distribution. As observed by Graham (1968), Parker and Watson (1970) and Bayliss (1987), aerial surveys are biased because of differences in visibility of different size classes due to behavior and observer bias. Unless corrections are made for these biases the size distributions will be misleading.

The most important assumption of any relative density index is that there is a linear relationship between it and the absolute density and that this relationship is stable over time (Bayliss 1987). Night-time eyeshine counts are highly correlated with water temperature and have been widely used to follow changes in population size for this reason. It has been suggested that the exact relationship between water temperature and the number of alligators observed (sighting fraction) may be dependent on the habitat, the population, and size class distribution (Bayliss 1978; Woodward and Marion 1978). In this study both the number of alligators in the population and the size class distribution have changed since Murphy's (1977) study in the 1970s. These changes may be the reason that the relationship between the number of alligators and water temperature in this study was best described by a quadratic equation rather than a linear relationship. Juveniles may be less active at the higher temperatures because they are more closely linked to their thermal environment, or they 
may be less visible because of the presence of vegetation during the warmer months. Despite the change in the form of the relationship, the percentage of the total population observed during night counts when water temperatures are between 25 and $30 \mathrm{C}$ is similar between the two studies (i.e. $25-35 \%)$. 
CHAPTER THREE
GROWTH AND SURVIVAL OF JUVENILE ALLIGATORS IN
PAR POND.

\section{INTRODUCTION}

Continual recruitment of individuals into the breeding population is an important characteristic of a stable or growing population. Female reproductive effort, and growth and survival of juveniles are important factors that affect adult recruitment and are critical components of population models. Population models have become of increasing interest to crocodilian biologists because of their applicability to harvest and management strategies. A problem with the construction and use of such models is that a general model may not be applicable to the entire range of the species because of interpopulational variability.

In constructing a model for the American alligator (Alligator mississippiensis) in Louisiana, Nichols (1976) commented on the lack of information on certain aspects of alligator population dynamics. He emphasized that this was true even in Louisiana where most studies on alligator biology have been conducted. He stated further that more information was needed concerning all aspects of population biology, particularly growth and survival of juveniles. Population structure, clutch size and growth rates of many reptiles including alligators (see Gibbons 1983 for turtles) show a great deal of variation between populations. Much of this variation may be due to geographic location, but local 
52

habitat conditions have been shown to be equally important for some species (Gibbons and Tinkle 1969). Estimates of yearly growth of juvenile alligators range from $11.9 \mathrm{~cm} / \mathrm{yr}$ in north Florida (Ditz 1979) to $34.1 \mathrm{~cm} / \mathrm{yr}$ in south Florida (Hines et al 1968). Mean clutch size ranges from to 30 the Okefenokee of Georgia (Metzen 1978) to 44 in coastal South Carolina (Wilkinson 1983). These factors affect the characteristics of the population. Other, less studied aspects such as survival rates will presumably also show large variation between populations and will also help to determine population characteristics.

The objective of this study was to examine the survival and growth of juvenile alligators in a reservoir in South Carolina. 
METHODS

This study was conducted on Par Pond, an 1120 ha cooling reservoir located on the Department of Energy's Savannah River site in Barnwell County, South Carolina (Gibbons and Sharitz 1981). Par Pond was created in 1958 by the impoundment of Corley Mill Pond and of Lower Three Runs Creek a tributary of the Savannah River. Both areas had resident populations of alligators that were probably the source for the current population.

Thermal effluent from R-reactor was discharged into the North Arm of Par Pond via Pond B from 1961-1964 and into the Hot Arm via Pond C from 1959 to the present. Temperature and duration of thermal discharge into the Hot Arm vary from year to year due to changes in reactor operations, with temperatures in the Hot Arm averaging 3-12 C above ambient when the reactor is operating at full power. Murphy and Brisbin (1974) and Murphy (1977) have shown that alligators, particularly adult males, may remain active in the area of thermal discharge during the winter while alligators in cooler areas are dormant. Periods of low or no discharge may last from a few days to several months. During this study (May 1986-May 1989) the reactor was only operational from May 1986-August 1987. Approximately $10 \%$ of Par Pond is affected by thermal effluent, the remaining $90 \%$ acts as a warm monomictic lake. Most of Par Pond's $53 \mathrm{~km}$ of shoreline is bordered by aquatic vegetation including Typha latifolia, Typha domingensis, Scirpus cyperinus, Nelumbo 
Iutea, and Nymphaea odorata (Parker et al 1973). In addition to the alligator there are 5 species of turtles, 28-30 species of fish, a large number of waterfowl and wading birds (Sharitz and Gibbons 1981), and numerous macrocinvertebrates (Thorp and Bergey 1981) that occur in and around Par Pond.

Aerial and ground surveys were used to locate alligator nests around Par Pond during the summers of 1987 and 1988 . When a nest was found, nest dimensions (length $\mathrm{x}$ width $\mathrm{x}$ height), clearing dimension, depth to top of clutch, number of eggs, length, width and mass of at least 10 randomly selected eggs, egg cavity dimensions, distance from water and general vegetation characteristics of the nest and habitat were recorded. An estimated date of laying was determined by measurement of the extent of banding on the eggs (Ferguson 1982). Nests were followed through incubation or until depredated. Hatchlings were captured as soon as possible after hatching and weighed, measured (total length, TL; snout vent length, SVL; skull length, SKL; and skull width, SKW) and marked, by clipping scutes, for individual identification and released at the site of capture.

Animals $\leq 1.25 \mathrm{~m}$ were captured at night from an airboat by hand or using a self-locking wire noose attached to PVC pipe. Morphometric measurements were taken as described above, animals were given an individual mark and released at the site of capture. Sex was determined for animals $>35 \mathrm{~cm}$ 
by cloacal examination using a nasal speculum. When possible, animals were assigned a code, indicating the year and nest from which they hatched.

Timing of captures was as follows: prior to october 1986, October 1986, July 1987, March, July, and September 1988. Most of the animals captured prior to July 1987 were less than 1 year old. Capture periods in July 1987, March 1988, and July 1988 consisted of three consecutive nights. All of Par Pond was searched each night. Animals captured the first and second nights were held until the third night when all animals were released.

Relative condition factors (or index of condition, Le Cren 1951) are a measure of the relative fatness of an individual, and can indicate how well an animal is doing in its environment (Taylor 1979). A positive correlation has been shown to exist between condition factor and growth in largemouth bass (Cooper et al 1963; Clugston 1974). If a similar relationship exists for alligators it may help to explain the variability in growth rates between populations.

Condition factors are derived from the relationship between length and weight in the population in the form $K=$ $M \times L^{-b}$ where $M=$ mass $(g)$ and $L=$ total length $(\mathrm{cm})$ and $b$ is the slope of the regression of in length on in mass. If growth is isometric $b=3$. In this case $b=3.2$; therefore, individual condition factors were calculated for all captures using the formula $\mathrm{K}=\mathrm{M} \times 10^{3} / \mathrm{L}^{3.2}$.

Growth rates were calculated for recaptured animals. 
Days between captures were classified as "growth" (March to october) or "no growth" (October to March) days (Chabreck and Joanen 1979), and growth expressed as SVL or SKL change per growth day (see Appendix A for conversions of SVL to TL) •

The Jolly-Seber model (Jolly 1965; Seber 1965) was used to estimate survival of known-age alligators from 13-21 months and 21-31 months. In addition, minimum-known-alive estimates (MKA) were determined for these two time periods and for 31-36 months. MKA estimates were calculated for each clutch when possible. 


\section{RESULTS}

Five nests were located prior to hatching between 1986 and 1988. In addition, data from 3 nests found prior to 1986 are also included. Mean clutch size ( \pm S.D.) was $48.8 \pm 3.69$ with a range of 44 to 54 . Eggs averaged $76 \pm 0.58$ $\mathrm{g}$, and had a mean length of $7.1 \pm 0.45 \mathrm{~cm}$ and width of $4.3 \pm 0.14 \mathrm{~cm}$ (Table 3). Egg size (length, width, and mass) differed significantly between nests (Kruskal-Wallis, $p<0.01$ ). Hatching success (the percentage of all eggs that hatch) varied between nests and between years (Table 3 ). Hatchling sizes were significantly different between nests (Kruskal-Wallis, $\mathrm{p}<0.01$ ) with a mean total length ( \pm S.D.) of $24.5 \pm 1.42 \mathrm{~cm}$ and a mean mass of $49.5 \pm 7.1 \mathrm{~g}$ (Table $4 a, b)$.

sizes of known-age alligators and growth rates for recaptured animals were based on 381 records for 149 individuals captured from 1986 to 1988. Of these, 251 records were from 82 known-age animals. Of these, $50 \%$ were recaptured once, $29.3 \%$ twice, $13.4 \% 3$ times, $3.7 \% 4$ times, 2.4\% 5 times and 1.2\%, 6 times. Capture intervals ranged from 5 to 2328 days with $32 \%$ being recaptured between 5 and 100 days, $14 \%$ between 101 and 200, 14.7\% between 201 and $300,17.38$ between 301 and $400,5.38$ between 401 and 500, and 19.98 after more than 501 days. Growth rates of the same age animals were not significantly different between 


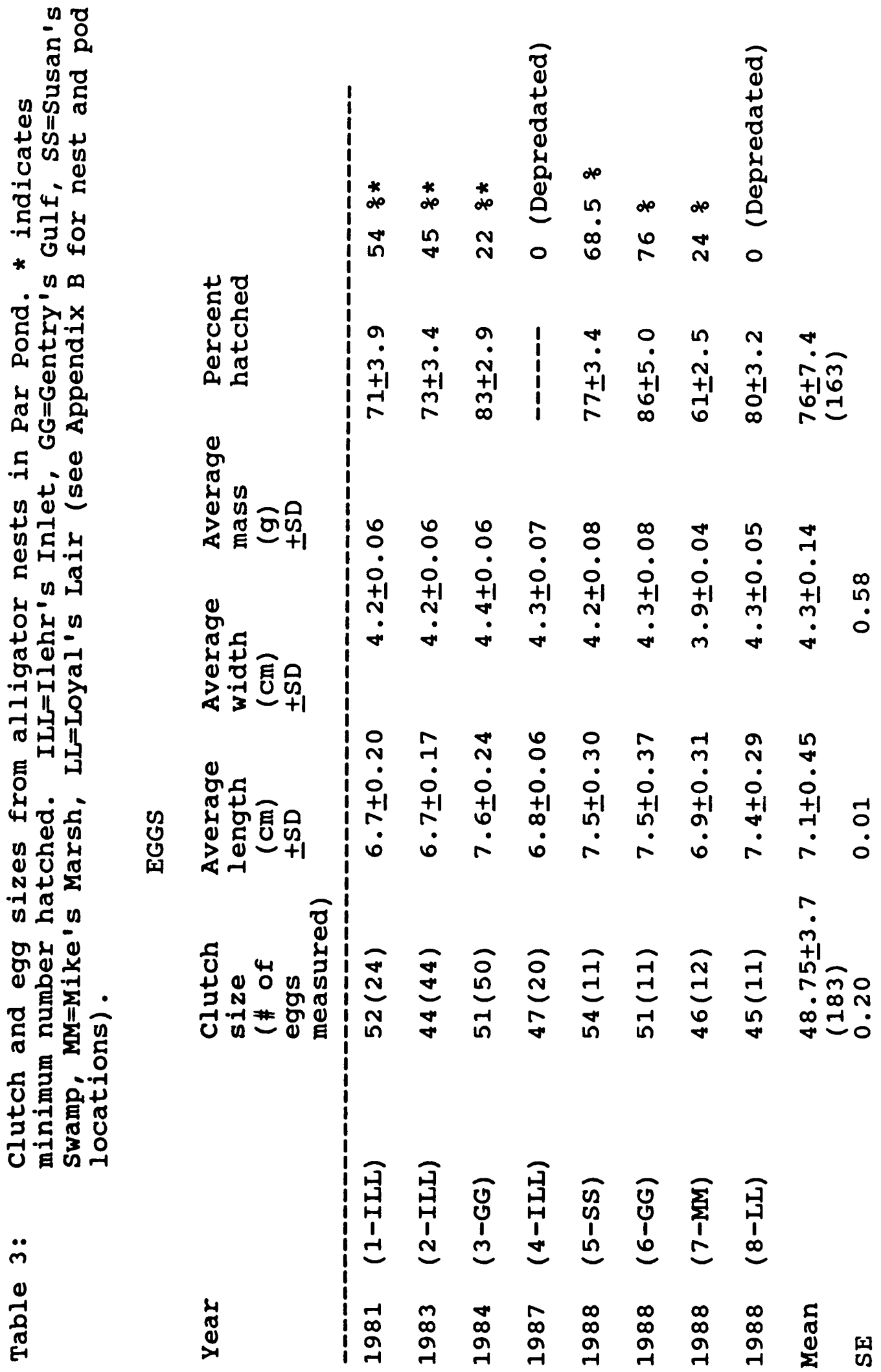




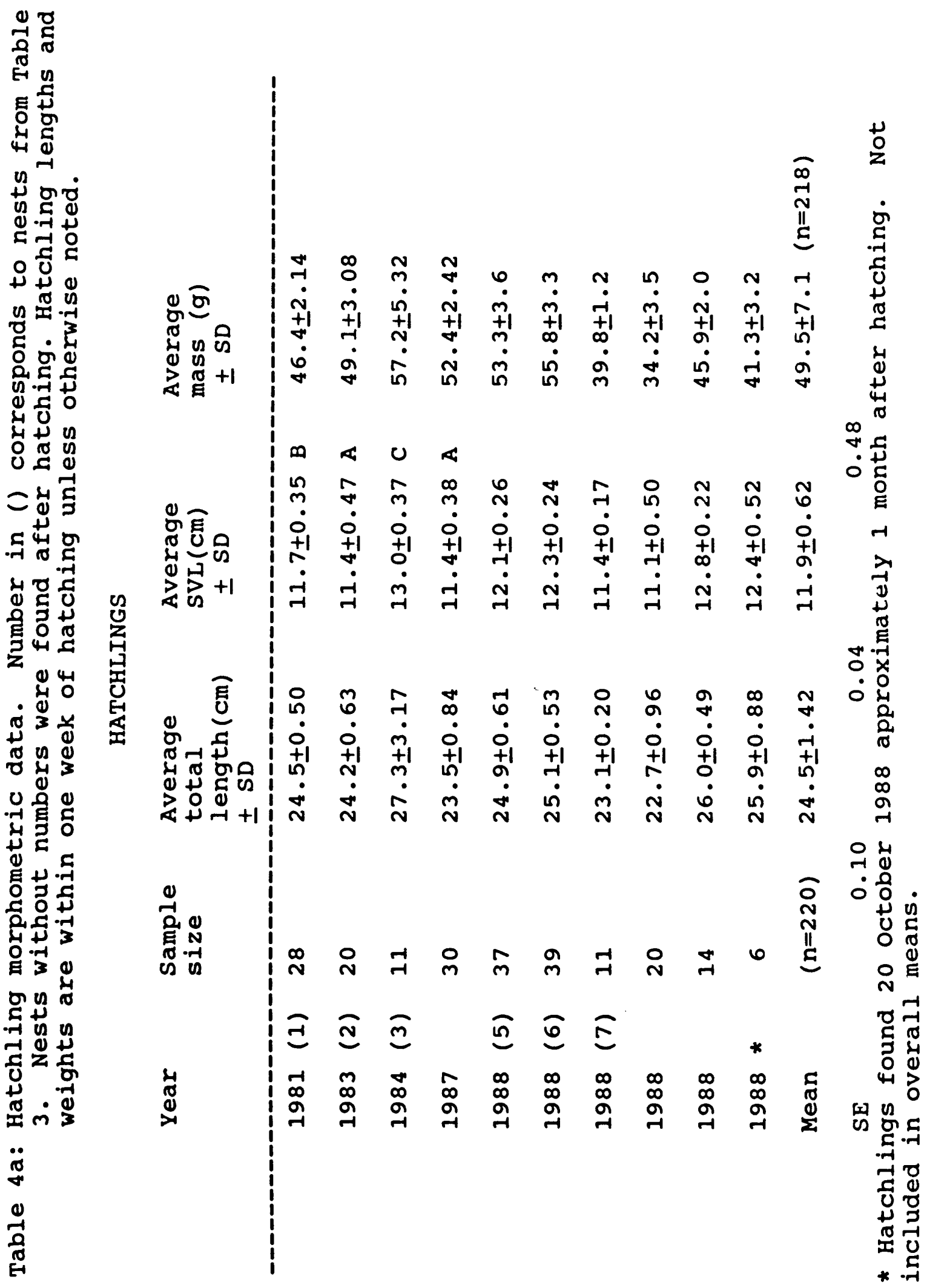


$\stackrel{4}{0}$

先

$\stackrel{+}{0}$

ב

gì

-न 0

동

ठิ

$+$

点



\%

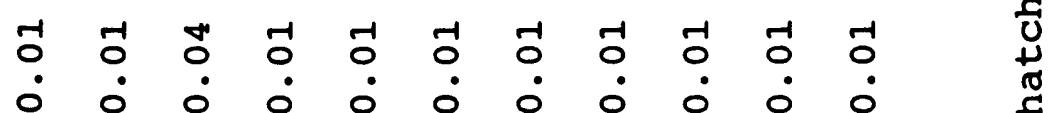

\begin{tabular}{lllllllllllll}
$\dot{0}$ & $\dot{0}$ & $\dot{0}$ & $\dot{0}$ & $\dot{0}$ & $\dot{0}$ & $\dot{0}$ & $\dot{0}$ & $\dot{0}$ & $\dot{0}$ & $\dot{0}$ & & \multicolumn{1}{c}{} \\
+1 & +1 & +1 & +1 & +1 & +1 & +1 & +1 & +1 & +1 & +1 & -1 & 4
\end{tabular}

난

어

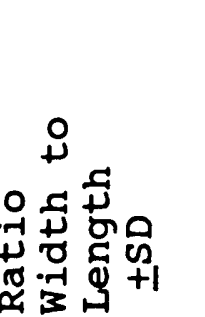

$\dot{0} 0$ :

(1)

$\mid \begin{array}{rrrrrrrrrrrr}-1 & -1 & 1 & -1 & -1 & 0 & -1 & -1 & -1 & -1 & 0 & \\ 0 & 0 & -1 & 0 & 0 & 0 & 0 & 0 & 0 & 0 & 0 & 0 \\ 0 & 0 & 0 & 0 & 0 & 0 & 0 & 0 & 0 & 0 & 0 & 0\end{array}$

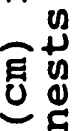

t)

$+$

ช

동

$+0$

던돈

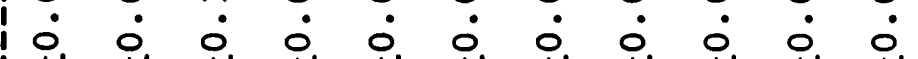

$\begin{array}{ccccccccccccc}0 & 0 & 0 & 0 & 0 & 0 & 0 & 0 & 0 & 0 & 0 & & 1 \\ +1 & +1 & +1 & +1 & +1 & +1 & +1 & +1 & +1 & +1 & +1 & m & -1\end{array}$

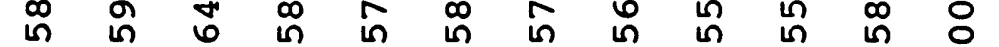

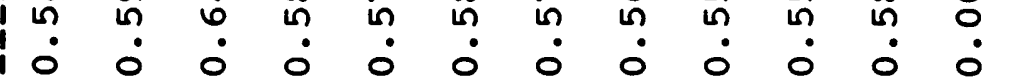

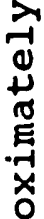

-r v

ब 15

4 工

ठํㅓㅇ

ธิ 0

욘단

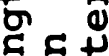

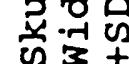

i

v $3+1$

().

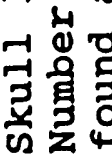

点葛

วิ

๘山+

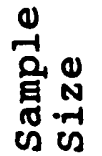

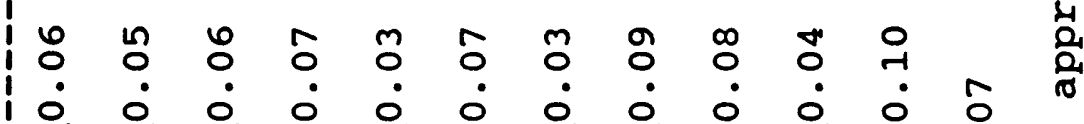

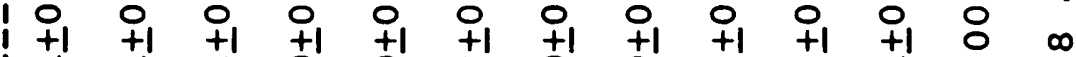

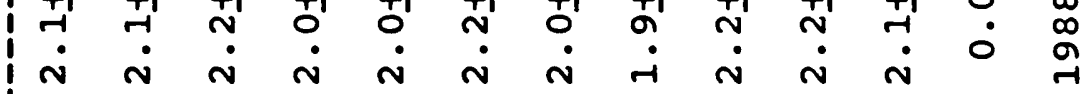

$\ddot{\circ}$

章

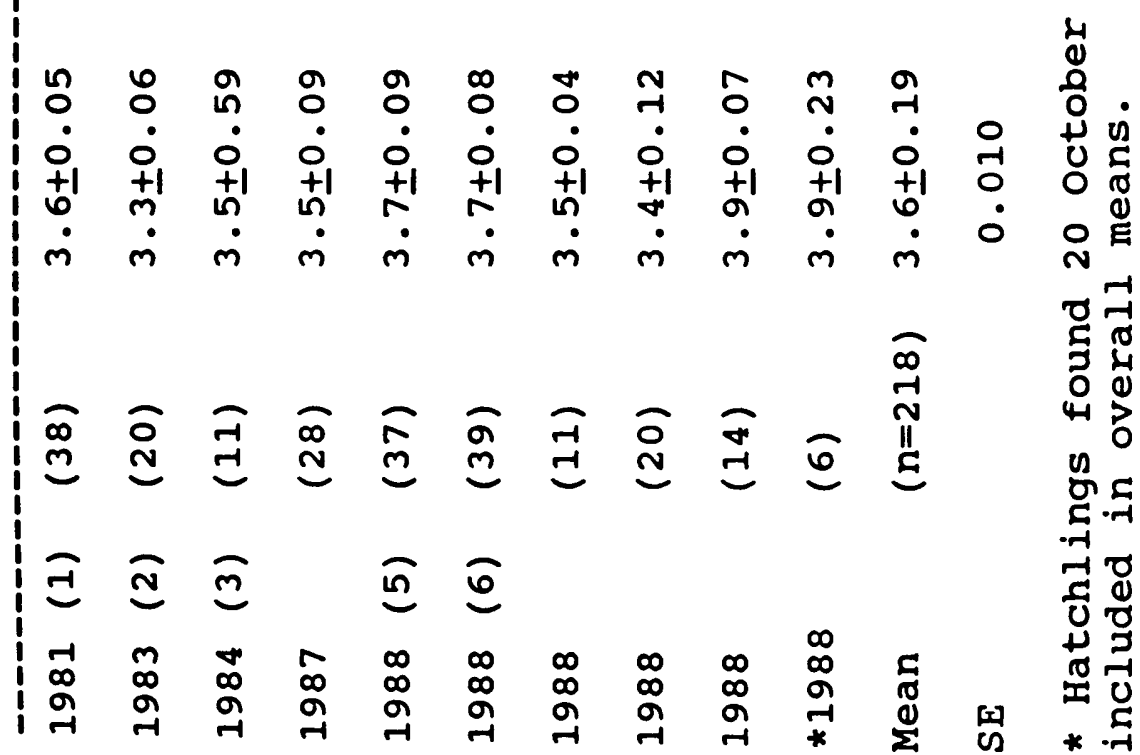


sexes or between clutches, however, sizes of animals of the same age but from different nests were significantly different (Kruskal-Wallis, p<0.01; Table 5).

Growth rates of animals less than 1 year were significantly greater than animals $1-2$ years and animals 1-3 years (Kruskal-Wallis, $p<0.001$ ). Mean growth rate for year 1 was $14.97 \pm 2.52 \mathrm{~cm} / \mathrm{Yr}$ SVL or $32.8 \pm 4.74 \mathrm{~cm} / \mathrm{Yr}$ TL. Growth rate from year 1 to year 2 was $10.0 \pm 3.84 \mathrm{~cm} / \mathrm{Yr} \mathrm{SVL}$, or $23.6 \pm 7.24 \mathrm{~cm} / \mathrm{Yr} T L$, year 2 to $38.30 \pm 5.38 \mathrm{~cm} / \mathrm{Yr} \mathrm{SVL}$ or $20.3 \pm 10.12 \mathrm{~cm} / \mathrm{Yr} \mathrm{TL}$. Average growth rate for years $1-3$ was $11.0 \mathrm{~cm} / \mathrm{yr}$ or $25.4 \mathrm{~cm} / \mathrm{Yr} \mathrm{TL}$. Most growth during year 1 occurred between June and september. Linear and non-linear regression equations were calculated for the relationship between age and size of animals $\leq 3$ years old (Figure 11). The linear regression equation (Size (SVL) $=17.272+$ 0.622 (age), $F=279.12$, d.f. $=1,117, p<0.001, r^{2}=0.706$ ) was not different from that found by Murphy (1977); however, the quadratic equation $(\mathrm{Size}(\mathrm{SVL})=11.196+1.34$ (age) $0.02\left(\mathrm{age}^{2}\right)$ fit the data better $(F=218.68$, d.f. $=2,115$, $\mathrm{p}<0.001, \mathrm{r}^{2}=0.792$ ).

Condition factors for 326 non-hatchling animals were lowest in the spring and highest in the late summer but were not significantly different by month (Figure 12). Hatchlings had significantly higher condition factors than all other animals (Kruskal-Wallis, $p<0.001$ ).

Survival rates were based on captures of 62 animals from 4 clutches that hatched in 1985. Pod size ranged from 7 to 


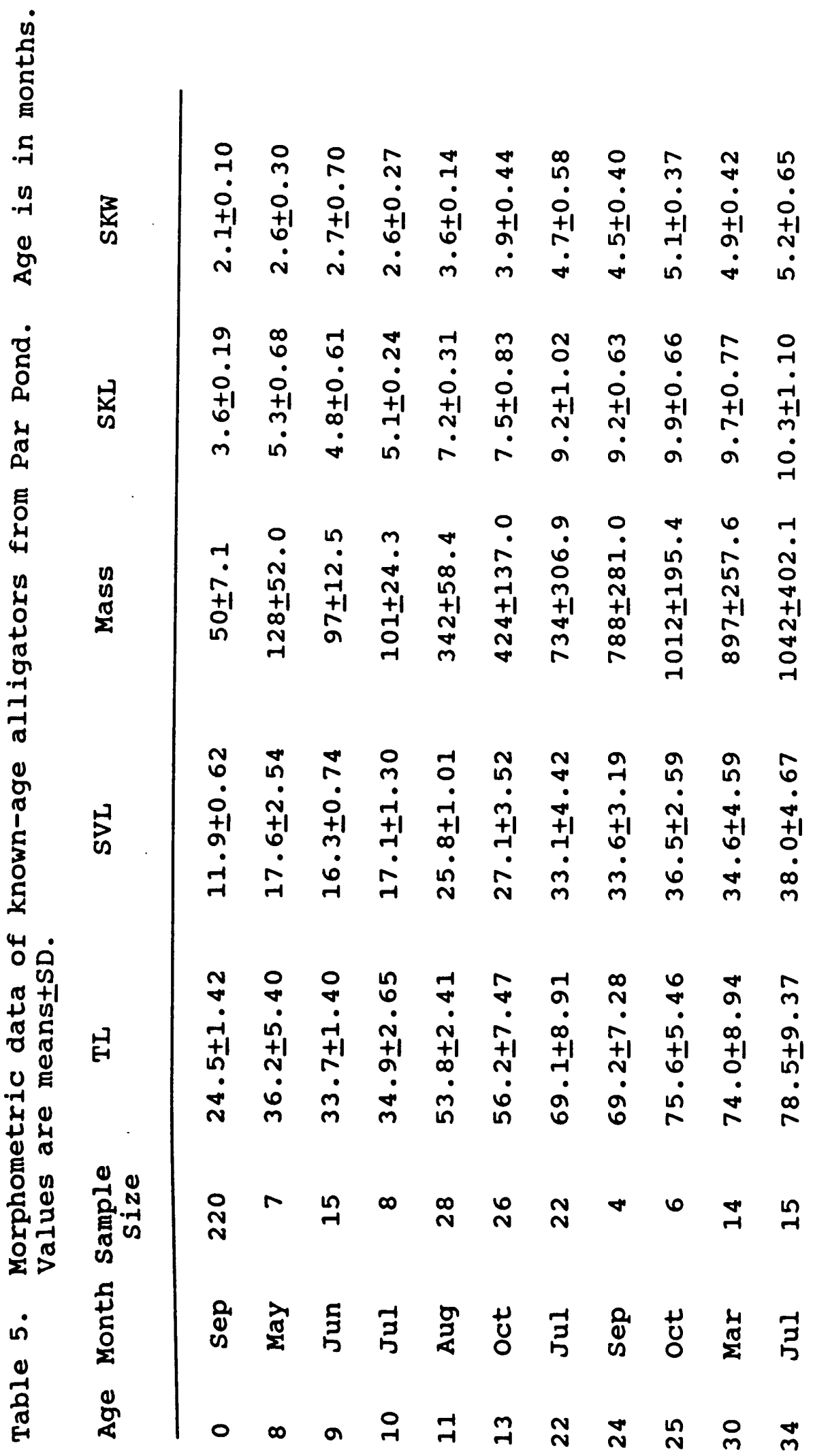




$$
63
$$




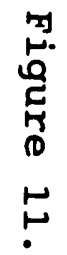

C2

O 5

s.

$8<$

35

ㄴ.

‥

จ

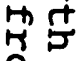

응

23

这

눙웅

$\infty$

욱

응

斿

01

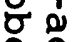

0

10

6

$\infty$.

是

5

II

捾

$\infty$

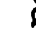

\%

:

(1)

5

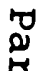

مอ 


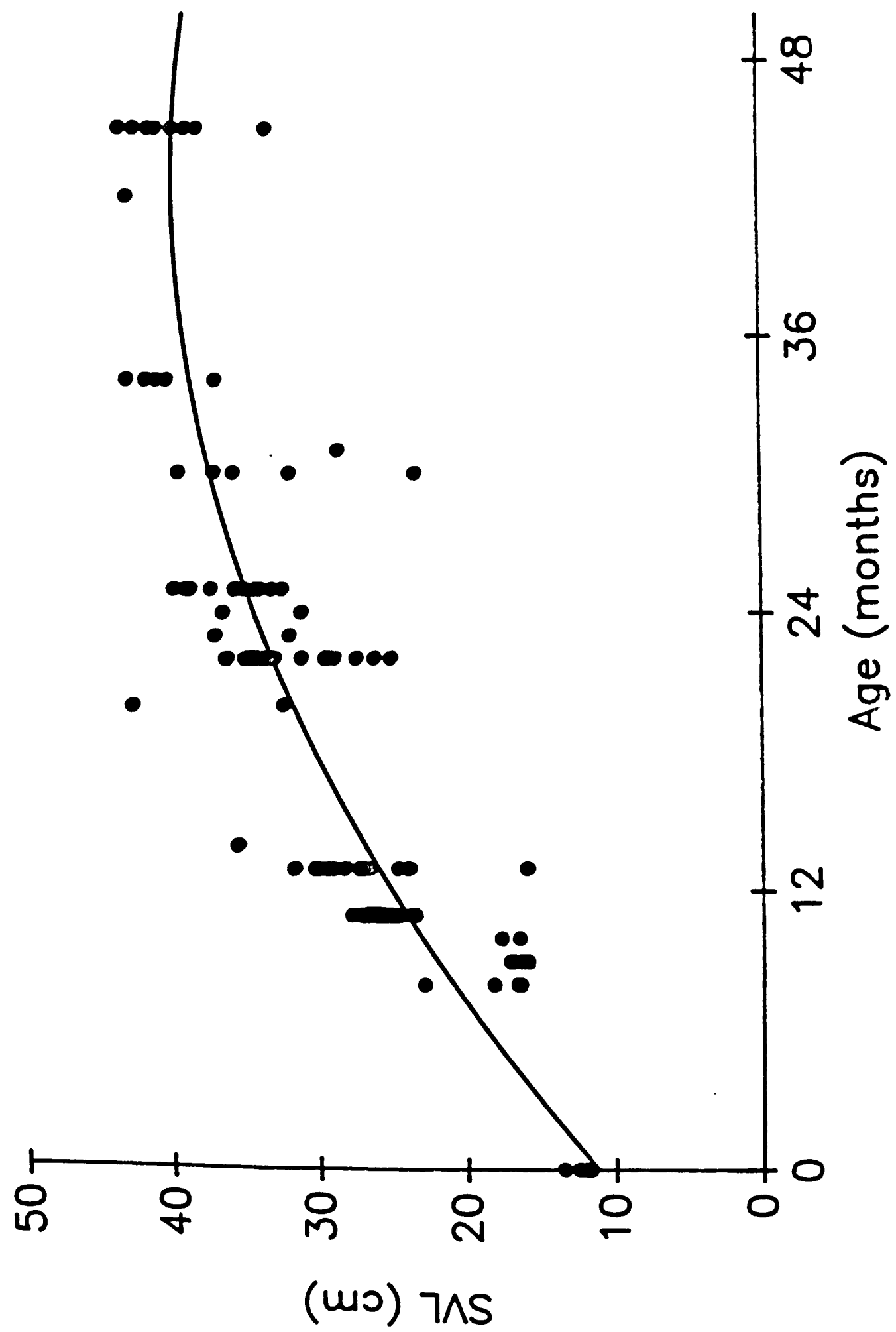




$$
\begin{aligned}
& \text { 年 } \\
& \stackrel{\sim}{\bullet}
\end{aligned}
$$

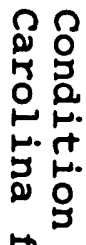

W

O

ษ

ख

$<$

เ

$\infty$

a

' 1

م

O

实

r

เง

$\infty$

$\infty$

का

요

N

त :

ภ

\%

อ

ט

.

D

5.

苋

'ั)

0
0
0
0
0
0 


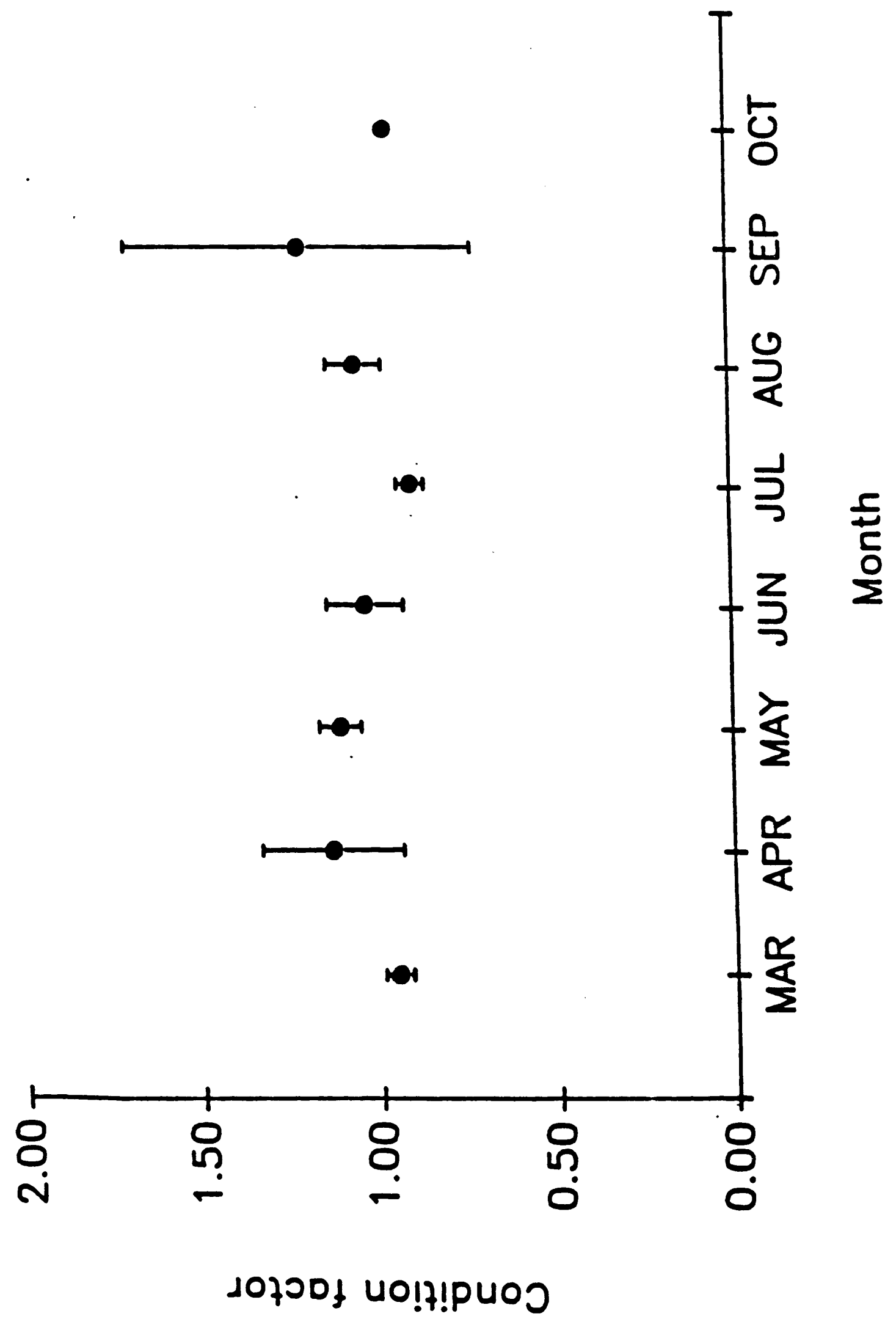


32. Extrapolating from mean clutch size and a mean hatch rate of $50 \%$ (based on observed hatch rate) gives a first-year estimated survival of approximately 0.63 for animals that hatched in 1985. In contrast the MKA survival estimate for hatchlings from the only clutch located in 1987 was 0.17 .

MKA estimates for all 5 clutches combined was 0.70 for age 13-21 months, 0.68 for age $21-31$, and 0.62 for $31-36$ months. Survival estimates calculated using the Jolly-Seber method were ( \pm S.E.) $0.88 \pm 0.202$ for 13-21 months and $1.09 \pm 0.415$ for $21-31$ months. 


\section{DISCUSSION}

clutch size, hatchling size, and growth rates are known to vary between populations of alligators. The mean clutch size from Par Pond $(48.8)$ is higher than means reported for coastal South Carolina (44.2, wilkinson 1983), the Okefenokee in Georgia (30.0, Metzen 1978), Georgia (39.4, Ruckel and Steele 1984), Louisiana (38.9, Joanen 1969), north-central Florida (37.5, Deitz and Hines 1980), and south Florida (33.1, Fogarty 1974). A similar pattern of geographic variation in clutch size (with larger clutch size being reported for populations in northern latitudes) has been reported for several species of turtles (Gibbons 1983). Gibbons (1983) offered two possible explanations for the observed pattern: (1) the turtles in more northern areas produce more smaller eggs, (2) the larger clutch size reported for populations in more northern areas is due to sampling error since the average clutch sizes for southern populations include second and third clutches which tend to be smaller. The latter explanation does not hold for alligators, as alligators produce at best one clutch per year. It is not possible to rule out the former explanation because of the limited data available on alligator clutch size and egg size from the different geographic areas; however, in this study mean egg size (76 g) was similar to that found by Deitz and Hines (77.5 $\mathrm{g}, 1980)$, and slightly lower than that reported by Ferguson (84 9, 1985), but total clutch mass was greater. 
Several other (untested) factors may help to explain the larger clutch size observed from Par Pond: (1) the nesting females in this study are larger or older than the females from the other studies. Ferguson (1985) has reported that female alligators between the ages of 15 and 30 years produce larger clutches than older or younger females. clutch size has been shown to be positively correlated with body size in turtles (Congdon and Gibbons 1983; Gibbons et al 1982; Tinkle et al 1981), and lizards (Ballinger 1973, Congdon et al 1978), and Joanen (1969) has reported a correlation between body size and clutch size in Louisiana alligators. (2) Locations of nests found at Par Pond suggest that an individual female does not nest every year. It may be that animals that skip a year, or more between nests may have more reserves for producing eggs when they do nest and can therefore produce more eggs. (3) The resource base of Par Pond may be greater than that from the other study areas. Par Pond has a high abundance of $f$ ish, particularly largemouth bass, Micropterus salmoides (Bennett and Gibbons 1974; personal observation). Because of the abundance of food in Par Pond, the alligators there may both eat more and spend less time and energy foraging. The energy "saved" could then be used for reproduction (more and/or larger eggs).

Mean hatching success (48.5\%) from all nests not destroyed by predators was lower than that reported by Joanen in IA $(1969,58.2 \%)$ or Metzen in GA $(1978,70 \%)$; 
however, $48.5 \%$ is an underestimate since all animals which hatched were not captured each year. The percentage of the eggs that hatch is variable between years as is the number of nests that actually hatch, because of predation, desiccation and flooding.

Survival of hatchlings to 12 months also varies between years and is related to nest placement and weather. If the quality of the habitat immediately around the nest is low, the hatchling will have a lower probability of surviving. If the winter is severe enough for ice to form over the surface of the coves, hatchlings will also have a lower probability of survival through the winter, as they are unable to maintain air holes in the ice and hence drown (Brandt and Mazzotti in revision). The severity of the winter of 1987-88 may account for the low survival of hatchlings from 1987. Many of the coves (including the one that the hatchlings were in) were frozen over for several days during January.

In contrast to low estimated survival of hatchlings from 1987, MKA of hatchlings from 1985 was approximately $63 \%$. This is slightly higher than the $19 \%$ MKA and the $41 \%$ Jolly-Seber estimate reported by Woodward et al (1987) the 35 and $30 \%$ MKA reported by Deitz (1979) for $\underline{A}$. mississippiensis, and the 38-46\% reported by Messel et al (1977) for hatchling Crocodylus porosus.

Survival estimates for alligators from years $1-2$ and 2-3 were higher than that from $0-1$, as expected. Overall 
estimates for survival from hatching to age 3 were higher than that found by woodward et al (1987), and slightly lower than those calculated by Nichols (1976) in his alligator population model (Table 6). The higher estimated survival rate in this study may reflect the fact that the entire Par Pond reservoir was searched when capture attempts were made so animals emigrating from the immediate nest site were still recaptured as well as the variability in survival between location and years. The slightly lower survival estimate for animals from age 2-3 reflects an increased wariness of individuals and movement into inaccessible areas, as well as actual survival. During the later capture intervals a higher proportion of animals from each pod were observed but not captured because of their wariness. Because of this the MKA survival estimates in this study are known to be underestimates. In addition, it is not possible at this time to distinguish between death and dispersal. There are many suitable areas in and around Par Pond which juveniles could move into, and animals $<1 \mathrm{~m}$ have been captured $3 \mathrm{~km}$ from their original capture site three months after their original capture. Three animals captured several $\mathrm{km}$ from their nest were later recaptured within 100 m of the nest, demonstrating both the homing and dispersalabilities of small alligators.

In this study, growth rates of animals from different clutches were not significantly different, but the sizes of the same age animals were significantly different 
Table 6: Cumulative and (interval) MKA survival rates for juvenile alligators from 5 clutches ( 4 from 1985, 1 from 1987) in Par Pond, Orange Lake, Florida (Woodward et al, 1987), and from a computer model (Nichols 1976).

MKA SURVIVAL RATE

AGE PAR POND

0

1

2

3
1.000

$0.524(0.524)$

$0.369(0.705)$

$0.155(0.419)$
ORANGE LAKE

1.000

$0.191(0.191)$

$0.042(0.176)$

$0.008(0.710)$
NICHOLS

1.000

$0.350(0.350)$

$0.210(0.600)$

$0.165(0.788)$ 
clutches. Because of the small number of clutches followed it was not possible to determine if alligators that hatched out slightly larger had a higher probability of surviving to a less vulnerable size. Hatchlings emerge in August or September. During October, water temperatures in Par Pond drop to 15-20 C, and the alligators become less active. Hatchlings entering this period are about the same size as at hatching and lose mass through the winter. Larger hatchlings may be better prepared to withstand this period of mass loss. Most of the hatchling growth seems to occur from May to september, and growth during the first year is greater than in subsequent years. As observed by Chabreck and Joanen (1979), alligators do not grow during the winter months (October to March) and emerge in the spring with lower condition factors because of a loss in mass over the winter. Condition factors increase and peak in April and then decrease again through the summer until september when they increase again. This may reflect the replenishment of energy reserves after the winter to a point at which energy can be put into growth in length. Chabreck and Joanen (1979) reported the highest growth rate for small alligators in IA during June and July, and the gradual decrease in the condition factor through the summer may reflect a combination of growth and a higher metabolic cost because of higher temperatures (Coulson and Hernandez 1964). In the fall, as temperatures and metabolic cost begin to decrease but food availability and consumption do not, condition 
again increases. A greater mass in the fall should increase the probability of winter survival and decrease the period in the spring when the animal does not grow because it is recovering from the winter.

The linear regression equation for growth of animals from hatching to 3 years from this study was not significantly different from that found by Murphy (1977) for the same population; however a quadratic equation also fit the data. The better fit of the quadratic expression reflects a slowdown in growth of the animals between 2 and 3 years of age. This has been observed for alligators $<3.5$ years old and $85 \mathrm{~cm}$ TL in Orange Lake (Abercrombie 1989), and by webb et al 1978 in young crocodylus porosus in Australia. In both studies there was an increase in the growth rate above this size.

The calculated mean yearly growth increment (25.4 $\mathrm{cm} / \mathrm{Yr}, \mathrm{TL})$ was similar to that reported by Murphy (22.0 $\mathrm{cm} / \mathrm{Yr}, \mathrm{TL}, \mathrm{1977)}$. It was higher than that reported by Fuller (1981) in NC $(12.4 \mathrm{~cm} / \mathrm{Yr} \mathrm{TL})$, Bara (1972) in SC (16.1 cm/yr), Deitz (1979) for several lakes in north FL $(11.9-21.1 \mathrm{~cm} / \mathrm{yr})$, about the same as the $22.0 \mathrm{~cm} / \mathrm{yr}$ reported by Chabreck and Joanen (1979) in LA, and lower than yearly growth reported by McIlhenny (1935) in LA (34.1) and Hines et al (1968) in south FL $(31.0 \mathrm{~cm} / \mathrm{yr})$. The variation in yearly growth rates observed between populations may be related to the geographic location, size of the animals followed, quality of the habitat, and the time of year in 
which captures are made. Because of this, caution should be used in making generalization from studies of a single population, particularly if they are single year studies. 


\section{CHAPTER FOUR \\ SUMMARY AND CONCLUSIONS}

The size and structure of the alligator population in Par Pond has changed significantly over the last 15 years. The number of alligators has approximately doubled (from 110 or 2.1 alligators $/ \mathrm{km}$ to 197 or 3.7 alligators $/ \mathrm{km}$ ) and the size distribution has shifted from one dominated by large adults to one with a high proportion of juveniles. The current sex-ratio is not significantly different from that found by Murphy (1977), however the average number of nests/yr has increased from 2.3 to 4.0 .

These changes are not surprising considering the history of the area. Par Pond was constructed in 1958 by impounding Lower Three Runs Creek and Corley Mill Pond. Both areas probably had resident alligator populations that became the original colonizers of Par Pond. During the 1970s study, Par Pond was only 15-20 years old and the alligator population was probably in the early stages of colonization. The original colonizers were probably a combination of large adults from the surrounding areas, and 1.25-1.5 m juveniles that were looking for suitable habitats to occupy. The few nests $(2.3 / \mathrm{yr})$ observed by Murphy (1977) may have reflected both the few actual number of breeding sized females and the fact that not every female nests every year. As the juvenile colonizers matured, they were able to contribute to the breeding population resulting in an increase in the number of nests and hence an increase in the 
juvenile size classes.

Night counts from this study were significantly higher than counts under similar conditions during the 1970s reflecting the increase in population size. Night counts were positively correlated with water temperature and 25-35\% of the estimated population was observed at water temperatures between 25 and $35 \mathrm{c}$. Because of the low approachability of the alligators, particularly during the later part of this study, size distributions could not be constructed from night counts.

The number of alligators observed by aerial surveys were highest in the spring and decreased through the summer. The relationship between night counts and aerial surveys was best expressed as a second order regression equation reflecting the seasonal variations in both types of surveys. Aerial surveys were biased toward adults and the size distribution observed varied between months. All monthly size distributions were different from the size distribution based on adult captures. Because of this variability aerial surveys should not be used to construct population size distributions unless they are verified. When combined with a marking study aerial surveys were useful for determining adult population size by resighting rather than recapturing animals. This technique would be particularly useful in situations where animals could not be physically recaptured due to wariness or man-power constraints. Clutch size averaged 49 (range 44-54) for 9 nests. 
There were significant differences in egg and hatchling size between nests. Growth rates of the same age animals (based on 381 records for 149 individuals) were not significantly different between sexes or between clutches for animals $\leq 3$ years. Growth rates of animals less than 1 year were significantly greater than those of animals age 1-3. $(32.9 \pm 4.74 \mathrm{~cm} / \mathrm{Yr} \mathrm{TL}$ and $21.6 \pm 7.24 \mathrm{~cm} / \mathrm{Yr} \mathrm{TL}$ respectively). Minimum known alive survival rates varied between years and between clutches. A minimum of $63 \%$ of the animals from 4 clutches from 1985 survived to 12 months. In contrast only $17 \%$ of the animals from 1 clutch in 1987 survived to 12 months. $37 \%$ of the alligators from all 5 clutches survived to 2 years and $16 \%$ to 3 years.

Based on the current status of the population, if conditions in Par Pond do not change the population should continue to increase over the 10-15 years. 


\section{APPENDIX A}

Regression equations for calculating unknown morphometric data from known measurements. Alligators ranged in size from 20.3 to $383 \mathrm{~cm} \mathrm{TL}$.

$\begin{array}{llc}\text { Equation } & r^{2} & \text { Sample size } \\ \mathrm{TL}=1.884(\mathrm{SVL})+4.673 & 0.996 & 501 \\ \mathrm{SVL}=0.5287(\mathrm{TL})+2.328 & 0.996 & 501 \\ \mathrm{SKL}=0.267(\mathrm{SVL})+0.340 & 0.996 & 498 \\ \mathrm{SVL}=3.732(\mathrm{SKL})+1.137 & 0.996 & 498\end{array}$




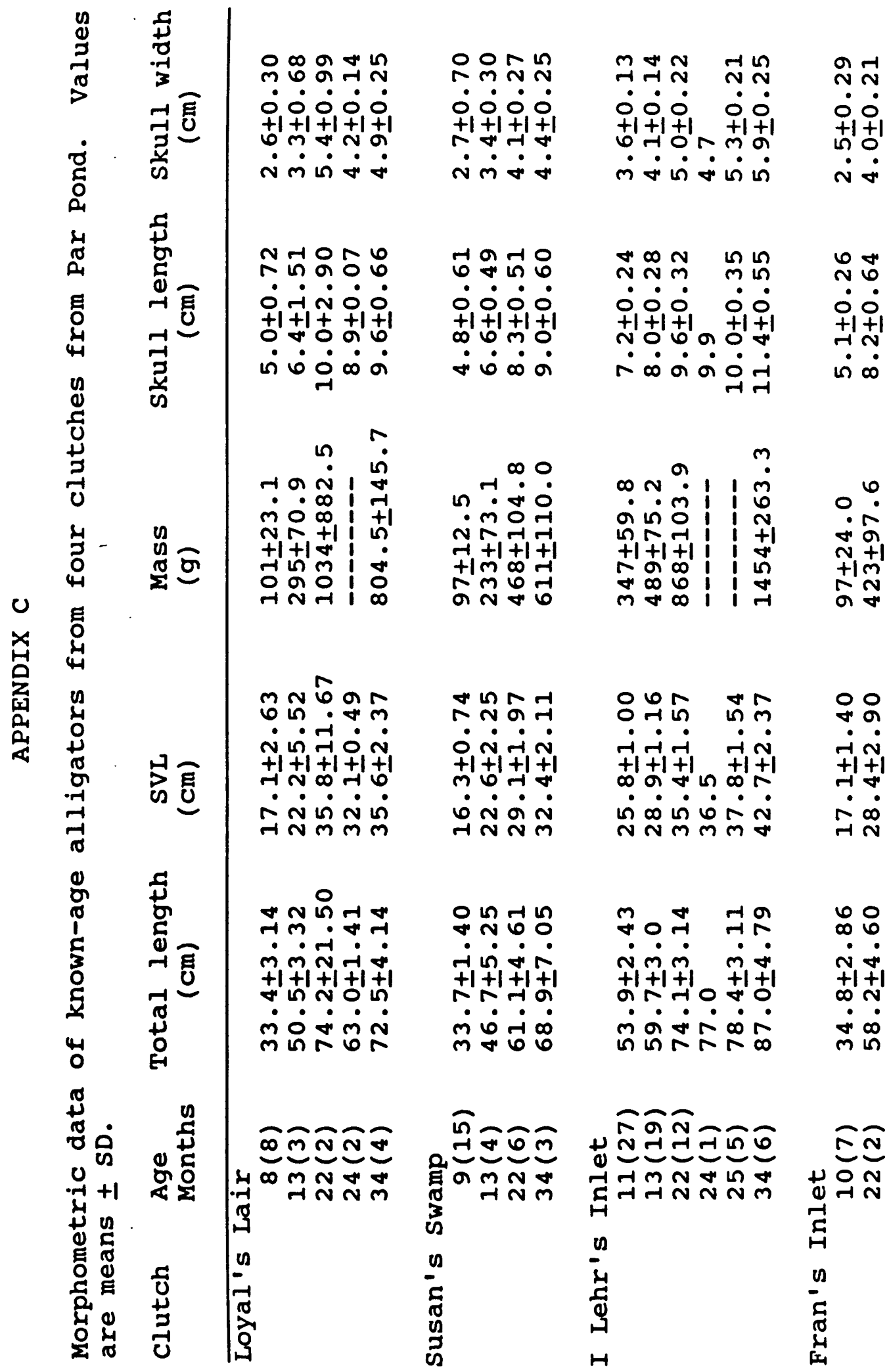




\section{LITERATURE CITED}

Abercrombie, C. L., III. 1989. Population dynamics of the American alligator. in Crocodiles their ecology, management and conservation. IUCN Croc. Specialists Group Publ. pp 1-16.

Ballinger, R. E. 1973. Comparative demography of two viviparous iguanid lizards (Sceloporus jarrovi and sceloporus poinsetti). Ecology 54(2)

Bara, M. O. 1971. Alligator research project annual progress report. South Carolina wildilife and Marine Resources Department, Columbia SC. 23pp.

- 1972. Alligator research project annual progress report. South Carolina Wildlife and Marine Resources Department, Columbia SC. 26pp.

- 1973. Alligator research project annual progress report. South Carolina Wildlife and Marine Resources Department, Columbia SC. 10pp.

- 1974. Alligator research project annual progress report. South Carolina Wildlife and Marine Resources Department, Columbia SC.

Bayliss, P. 1987. Survey methods and monitoring within crocodile management programs. in G. J. W. Webb, S. C. Manolis and P. J. Whitehead, eds. Wildlife Management: Crocodiles and Alligators. Surrey Beatty and Sons, Sydney. pp. 157-175.

, G. J. W. Webb, P. J. Whitehead, K. Dempsey, A. Smith. 1986. Estimating the abundance of Saltwater crocodiles, crocodylus porosus, in tidal wetlands of the Northern Territory: A mark-recapture experiment to correct spotlight counts to absolute numbers and the calibration of helicopter and spotlight counts. Aust. Wildl. Res. 13:309-320.

Bennett, D. H. and J. W. Gibbons. 1974. Growth and condition of juvenile largemouth bass from a reservoir receiving thermal effluent. in J. W. Gibbons and R. R. Sharitz eds. Thermal Ecology. US Atomic Energy Comm. Symposium Service. Springfield, VA. pp. 246-254.

Brisbin, I. 1. Jr., C. A. Ross, M. C. Downes, M. A. Staton, and B. R. Gammon. 1986. A bibliography of the American alligator (Alligator mississippiensis). Savannah River National Environmental Research Park. SRO-Nerp 13. 310pp. 
Caughley, G. 1974. Bias in aerial survey. J. Wildl. Manage. $38(4): 921-933$.

Chabreck, R. H. 1966. Methods of determining the size and composition of alligator populations in Louisiana. Proc. Ann. Conf. S.E. Assoc. Game and Fish Comm. $20: 105-112$.

Chabreck, R. H. and T. Joanen. 1979. Growth rates of American alligators in Louisiana. Herpetologica. $35(1): 51-57$.

Clugston, J. P. 1964. Growth of the Florida largemouth bass, Micropterus salmoides floridanus (Lesueus), and the northern largemouth bass, M. S. salmoides (Lacepede), in subtropical Florida. Trans. Amer. Fish. Soc. $93(2): 146-154$.

Cooper, E. L., H. Hidu, and J. K. Andersen. 1963. Growth and production of largemouth bass in a small pond. Trans. Amer. Fish. Soc. 92(4):391-400.

Congdon, J. D. and J. W. Gibbons. 1983. Relationships of reproductive characteristics to body size in Pseudemys scripta. Herpetologica $39(2): 147-151$.

, L. J. Vitt, and N. F. Hadley. 1978. Parental

investment: comparative reproductive energetics in bisexual and unisexual lizards. Genus cnemidophorus. Am. Nat. $112(985): 509-521$.

Coulson, R.A. and T. Hernandez. 1964. Biochemistry of the alligator. Louisiana State University Press, Baton Rouge, IA. pp.

Deitz, D. C. 1979. Behavioral ecology of young American alligators. Unpubl. Ph.D. Diss. University of Florida, Gainesville, FL. 151 pp.

Deitz, D. C. and T. C. Hines. 1980. Alligator nesting in north-central Florida. Copeia. $1980(2): 249) 257$.

Ferguson, M. W. J. 1982. The structure and composition of the eggshell and embryonic membranes of Alligator mississippiensis. Trans. Zool. Soc. Lond. 36:99-152.

Ferguson, M. W. J. 1985. Reproductive biology and embryology of the crocodilians. in Biology of the Reptilia Vol 14A. C. Gans, F. Billett, P. F. A. Maderson eds. and T. Joanen. 1982. Temperature of egg incubation determines sex in Alligator mississippiensis. Nature $296(5860): 850-853$. 
Fogarty, M. J. 1974. The ecology of the everglades alligator. in Environments of south Florida: present and past. P. J. Gleason ed. pp. 367-374.

Fuller, M. K. 1981. Characteristics of an American alligator (Alligator mississippiensis) population in the vicinity of Lake Ellis Simon, North Carolina. Unpubl. MS thesis, North Carolina State University, Raleigh, NC. 136 pp.

Gibbons, J. W. 1983. Reproductive characteristics and ecology of the mud turtle Kinosternon subrubrum (Lacepede). Herpetologica 39(3):254-271.

and R. R. Sharitz. 1981. Thermal ecology: environmental teachings of a nuclear reactor site. Bioscience 31(4):293-298.

and D. W. Tinkle. 1969. Reproductive variation between turtle populations in a single geographic area. Ecology $50(2): 340-341$.

, J. L. Greene, and K. K. Patterson. 1982. Variation in reproductive characteristics in aquatic turtles. Copeia pp. 776-784.

Goodwin, T. M. and W. R. Marion. 1978. Aspects of the nesting ecology of American alligators (Alligator mississippiensis) in north-central Florida. Herpetologica $34(1):$ 43-47.

and

1979. Seasonal activity ranges and habitat preferences of adult alligators in a north central Florida lake. J. Herp. 13(2):157-164.

Graham, A. 1968. The Lake Rudolf crocodile (Crocodylus niloticus Laurenti) population. Report to the Kenya Game Department. Nairobi, Kenya. pp.

Grigg, G. C. 1979. Aeronautical aspects of aerial survey. in Aerial surveys of fauna populations. Australian National Parks and Wildl. Service Spec. Publ. no 1.

Groombridge, B. 1987. The distribution and status of world crocodilians. in G. J. W. Webb, S. C. Manolis and P. J. Whitehead eds. Wildlife Management: Crocodiles and alligators. Surrey Beatty and sons. Australia. pp 9-21.

Hines, T. C., M. J. Fogarty, and L.C. Chappell. 1968 . Alligator research in Florida: a progress report. Proc. S. E. Assoc. Game and Fish Comm. 22:166-180. 
Joanen, T. 1969. Nesting ecology of the alligator in Louisiana. Proc. Ann. Conf. S.E. Assoc. Game and Fish Comm. $23: 141-151$.

and L. McNease. 1970. A telemetric study of nesting female alligators on Rockefeller refuge, Louisiana. Proc. Ann. Conf. S.E. Assoc. Game and Fish Comm. $24: 175-193$.

and 1972. A telemetric study of adult male alligators on Rockefeller refuge Louisiana. Proc. Ann. Conf. S.E. Assoc. Game and Fish Comm. 26:252-275.

and 1975. Notes on the reproductive biology and captive propagation of the American alligator. Proc. Ann. Conf. S.E. Assoc. Game and Fish Comm. $29: 407-415$.

Joanen, T. and L. McNease. 1981. Management of the alligator as a renewable resource in Louisiana. Ga. Dept. of Nat. Res. Tech. Bull. WL 5:62-72.

Jolly, G. M. 1965. Explicit estimates from capture-recapture data with both death and immigration-stochastic models. Biometrika 52:225-246.

Lang, J. W. 1987. Crocodilian thermal selection. in G. J. W. Webb, S. C. Manolis and P. J. Whitehead eds. Wildlife Management: Crocodiles and alligators. Surrey Beatty and sons. Australia.

Lecren, E. D. 1951. The length/weight relationship and seasonal cycle in gonad weight and condition in the perch (Perca fluviatilis). J. Anim. Ecol. 20:201-219.

Magnusson, W. E. 1982. Techniques of surveying for crocodilians Proc. 5th working meeting CSG SSC/IUCN Gland, Switzerland. pp 389-403.

G. J. Caughley and G. C. Grigg. 1978. A double survey estimate of population size from incomplete counts. J. wildl., Manage. 42:174-176.

McIlhenny, E. A. 1935. The Alligator's life history. Christopher Publishing House, Boston. 117 pp.

McNease, L. and T. Joanen. 1974. A telemetric study of immature alligators on Rockefeller Refuge Louisiana. Proc. Ann. Conf. S.E. Assoc. Game and Fish Comm. $28: 482-500$.

and 1978. Distribution and relative abundance of the alligator in Louisiana coastal marshes. Proc. Ann. Conf. S.E. Assoc. Game and Fish Comm. 32:182-186. 
Messel, H. and G. C. Vorlicek. 1986. Population dynamics and status of crocodylus porosus in the tidal waterways of northern Australia. Aust. Wildl. Res. 13:71-111.

Metzen, W. D. 1977. Nesting ecology of alligators on the okefenokee National Wildlife Refuge. Proc. Ann. Conf. S.E. Assoc. Game and Fish Comm. 31:29-32.

Murphy, T. M. 1977. Distribution, movement and population dynamics of the American alligator in a thermally altered reservoir. Unpublished M.S. Thesis. University of Georgia, Athens. $58 \mathrm{pp}$.

- 1981. The population status of the American alligator on the Savannah River Plant, South Carolina. National Environmental Research Park. SRO-Nerp-4. 20 pp.

and I. L. Brisbin. 1974. Distribution of alligators in response to thermal gradients in a reactor cooling reservoir. in Thermal Ecology. J. W. Gibbons and R. R. Sharitz eds. AEC Symp. Ser. (Conf. 730505). USAEC TIC, Oak Ridge, TN. pp. 313-321.

and T. T. Fendley. 1973. A new technique for live trapping of nuisance alligators. Proc. S.E. Assoc. Fish and Game Comm. 27:308-311.

and J. C. Fuller. Jr. 1982. American alligator investigations management recommendations and current research 1982. S.C. Wildlife and Marine Resources Department Report, Columbia. 93 pp.

Nichols, J. D. 1976. Development and application of a model for simulating alligator population dynamics. Ph.D. Dissertation. Michigan State University, East Lansing. $112 \mathrm{pp}$.

and R. H. Chabreck. 1980. On the variability of alligator sex ratios. Am. Nat. 116:125-137.

' atas ind $\mathrm{w}$. Conley. 1976. The use of restocking Am. Wildl. Nat. Res. Conf. 41:385-395.

Parker, I. S. C. and R. M. Watson. 1970. Crocodile distribution and status in the major waters of western and central Uganda in 1969. E. Afr. Wildl. J. $8: 85-103$.

Parker, E. D., M. F. Hirshfield, and J. W. Gibbons. 1973. Ecological comparisons of thermally affected aquatic environments. J. Water Poll. Control Fed. $45(4): 726-733$. 
Ruckel, S. W. and G. W. Steele. 1984. Alligator nesting ecology in two habitats in southern Georgia. Ann. Conf. S.E. Assoc. Fish and Wildl. Agencies. 38:212-221.

Seber, G. A. F. 1965. A note on the multiple recapture census. Biometrika 52:249-259.

Seigel, R. A., L. A. Brandt, J. L. Knight, and S. S. Novak. 1986. Ecological Studies on the American alligator (Alligator mississippiensis) on the Savannah River Plant. CCW Final report. SREL-26. UC-66e. 41 pp.

Sharitz, R. R. and J.W. Gibbons. 1981. Effects of thermal effluents on a lake: enrichment and stress. in G. W. Barrett and R. Rosenberg, eds. Stress Effects on Natural Ecosystems. John Wiley and Sons.

Spotilia, J. R. 1974. Behavioral thermoregulation of the American alligator. in J. W. Gibbons and R. R. Sharitz eds. Thermal Ecology. US Atomic Energy Comm. Symposium service. Springfield, VA. pp. 322) 334 .

Taylor, J. A. 1979. The foods and feeding habits of subadult Crocodylus porosus Schneider in Northern Australia. Aust. Wildl. Res. 6:347-359.

Taylor, D. and W. Neal. 1984. Management implications of size-class frequency distributions in Louisiana alligator populations. Wildl. Soc. Bull. 12:312-319.

Thompson, R. L. and C.S. Gidden. 1972. Territorial basking counts to estimate alligator populations. J. Wildl. Manage. $36(4): 1081-1088$.

Thorp, J. H. and E. A. Bergey. 1981. Field experiments on responses of a freshwater, benthic macroinvertebrate community to vertebrate predators. Ecology $62(2): 365-$ 375 .

Tinkle, D. W., J. D. Congdon, and P. C. Rosen. 1981. Nesting frequency and success: implications for the demography of painted turtles. Ecology 62:1426-1432.

Walthers J. and I. IvY. 1964. Alligator kill survey records from Sabine National Wildlife Refuge. Unpublished manuscript.

Webb, G. J. W., S. C. Manolis and P. J. Whitehead. 1987. eds. Wildlife Management: Crocodiles and alligators. Surrey Beatty and sons. Australia. 552 pp.

, H. Messel, J. Crawford, and M. J. Yerbury. 1978 . Growth rates of Crocodylus porosus (Reptilia: 
Crocodilia) from Arnhem Land, Northern Australia. Aust. Wildl. Res. 5:385-399.

Wilkinson, P. M. 1983. Nesting ecology of the American alligator in coastal South Carolina. Study completion report. South Carolina Wildlife and Marine Resources, Charleston. $113 \mathrm{pp}$.

Wood, J. M., A. R. Woodward, S. R. Humphrey, and T. C. Hines. 1985. Night counts as an index of American alligator population trends. Wildl. Soc. Bull. $13(3): 262-272$.

Woodward, A. R. and w. R. Marion. 1978. An evaluation of factors affecting night-light counts of alligators. Proc. Ann. Conf. S.E. Assoc. Fish \& Wildl. Agencies $32: 291-302$.

T. C. Hines, C. L. Abercrombie, and J. D. Nichols. 1987. Survival of young American alligators on a Florida lake. J. Wildl. Manage. 51(4):931-937. 
VITA

The Status and Ecology of the American alligator (Alligator mississippiensis) in Par Pond, Savannah River Site.

Laura Ann Brandt was born in Pittsburgh, Pennsylvania on 23 August 1962. Her parents are Gerald Bennett Brandt and Susan E. Brandt. She received her elementary education at Turner and Semple Elementary schools, and Wilkinsburg Jr. High School, Wilkinsburg, Pennsylvania. She completed her secondary education at Edgewood High School, Edgewood, Pennsylvania in 1980. In september 1980 she entered The Pennsylvania State University, University Park, Pennsylvania and was graduated with a BS degree in Biology with a Minor in Marine Sciences in December 1983. While at Penn state she worked as a Research Assistant in the Department of Biology. From 1985-1986 she was employed as a Research Technician at the University of Georgia's Savannah River Ecology Laboratory. Laura received a Graduate student Travel Grant from Oak Ridge Associated Universities, and a Graduate student Fellowship through the Savannah River Ecology Laboratory to support her graduate research. She is an Associate member of Sigma $X i$ and is currently employed as a Research Associate at the Broward County Extension office in Davie, Florida. 